TOURISM TORONTO'S “HOW TO EAT..." GUIDES: A GLOBAL CITY'S MAP TO CULINARY COLONIALISM

by

pruneah Michelle Kim, BA (Hons.), University of Toronto, 2017

\author{
A Major Research Paper \\ presented to Ryerson University
}

in partial fulfillment of the requirement for the degree of

Master of Arts in the program of Immigration and Settlement Studies

Toronto, Ontario, Canada, 2019

Cpruneah Michelle Kim, 2019 


\section{AUTHOR'S DECLARATION FOR ELECTRONIC SUBMISSION OF A MAJOR RESEARCH PAPER (MRP)}

I hereby declare that I am the sole author of this Major Research Paper. This is a true copy of the MRP, including any required final revisions.

I authorize Ryerson University to lend this MRP to other institutions or individuals for the purpose of scholarly research.

I further authorize Ryerson University to reproduce this MRP by photocopying or by other means, in total or in part, at the request of other institutions or individuals for the purpose of the scholarly research.

I understand that my MRP may be made electronically available to the public.

pruneah Michelle Kim 


\title{
TOURISM TORONTO'S "HOW TO EAT..." GUIDES: A GLOBAL CITY'S MAP TO CULINARY COLONIALISM
}

\author{
pruneah Michelle Kim \\ Master of Arts (2019) \\ Immigration and Settlement Studies \\ Ryerson University
}

\begin{abstract}
By focusing on Toronto as a "global city" (Sassen, 1991), the main objective of this Major Research Paper is to examine the contradictory relationship between Toronto's discourse of "food multiculturalism" (Flowers \& Swan, 2012) and processes of "culinary colonialism" (Heldke, 2003). This paper will use Tourism Toronto's “How To Eat...” guides as a case study of Toronto's discourse of food multiculturalism. Through critical discourse analysis, this paper demonstrates how Toronto's discourse of food multiculturalism depends on colonial assumptions that commodify its racialized immigrants and diaspora as the Other. Consequently, this paper finds that Toronto's global city strategy is critically linked to culinary colonialism. Furthermore, this paper conceptually builds on culinary colonialism by emphasizing food adventuring as a performative act of the Other. Within this context, these guides also operate as an intimate map for individual eaters to perform 'the Other' through food.
\end{abstract}

Key Words: Global city; Food Multiculturalism; Culinary Colonialism; Performance Theory; Critical Discourse Analysis 


\section{ACKNOWLEDGEMENTS}

I would like to thank my supervisor, Dr. Cheryl Teelucksingh who has been the most meticulous and caring mentor. Thank you for believing in my ideas. Your guidance made them better.

I would also like to thank Dr. Mustafa Koç, my second reader, for always being generous and supportive.

To my birds, thank you for grounding this work in something worthwhile. A special thank you to my dearest Janika and Yusheng. And my sisters, 언 니, Jae, Haedeun and Olive.

엄마, 아빠, this Major Research Paper is dedicated to you.

For teaching me that there is nothing more beautiful than eating together. 


\section{TABLE OF CONTENTS}

AUTHOR'S DECLARATION FOR ELECTRONIC SUBMISSION OF A MAJOR RESEARCH PAPER
(MRP)

A POSTCOLONIAL FOOD LENS: THEORETICAL BACKGROUND .......................................................... 4

TORONTO AS 'GLOBAL CITY’: CONTEXTUAL BACKGROUND …............................................................ 8

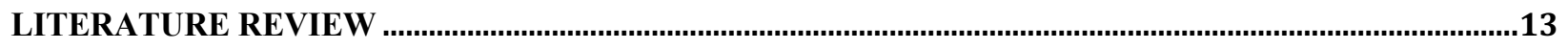

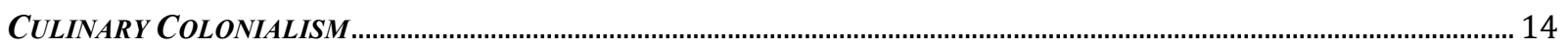

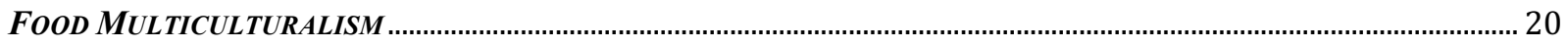

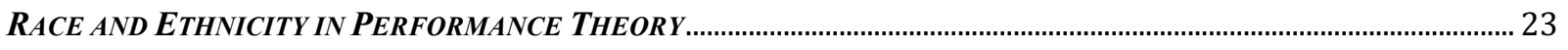

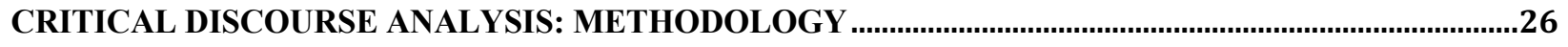

DISCUSSION

NOVELTY

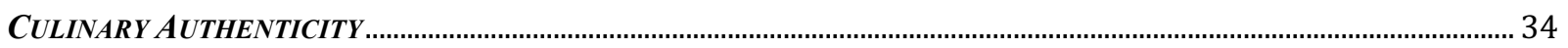

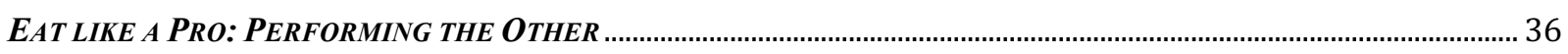

CONCLUSION

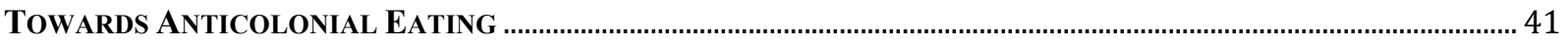

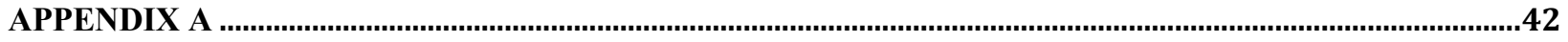

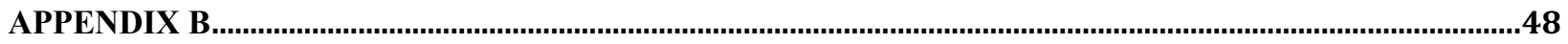

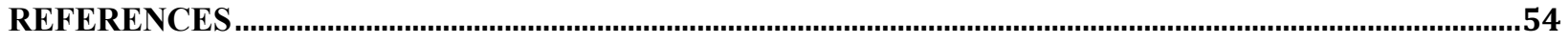




\section{Introduction}

On the very first page of Tourism Toronto’s “Eat \& Drink” page, you can click on a “How To Eat..." link ${ }^{1}$ (Tourism Toronto, 2019). This link leads to a series of five infographic guides in which a rosy cheeked blonde boy helps you overcome your "intimidation" of five "ethnic foods" so that you can "eat like a pro" (read: eat like Them) (Tourism Toronto, 2019). It includes a brief explanation of the food, its ethnic origin, the method of consumption and the intimate do's and don'ts that pertain to each food item. This guide is an example of the many "How to Eat..." (henceforth HTE) resources that have been circulating recently on the web as one's savviness around ethnic food is increasingly becoming a marker of the desirable cosmopolitan subject (see Cappeliez \& Johnston, 2013 and Wise, 2011 for more). By extension of this logic, Toronto often articulates its status as the "world's most multicultural city" through the promotion of its diverse ethnic foodscape. This strategy is referred to as "food multiculturalism" (Flowers and Swan, 2012) and will be the focus of this Major Research Paper.

The given HTE guides are produced and circulated by Tourism Toronto, the "official destination marketing organization" (Tourism Toronto, 2019b) for Toronto, on their official website. This website is funded by the City, amongst other public and private partners, to market Toronto as the next destination for tourists and global investment. Consequently, these guides become productive sites of analysis for two main reasons. First, by examining these guides as an example of the city's marketing strategy, I can demonstrate how Tourism Toronto uses a

\footnotetext{
${ }^{1}$ See Appendix A. All citations regarding Toronto Tourism's “How To Eat...” guide can be found here.
} 
discourse of food multiculturalism to brand Toronto as a burgeoning "global city" (Sassen, 1991). Although there is growing scholarship on the use of culture and diversity to market global cities (Florida, 2003; Jacobs 1996, 1998; Jacobs \& Fincher, 1998; Kipfer and Keil, 2002), I am interested in how food is used to sell multiculturalism that enables cities like Toronto to emerge as a global city in the first place.

Second, by adopting recent developments in postcolonial food scholarship, I will use these guides to demonstrate how Toronto's discourse of food multiculturalism enacts material processes of "culinary colonialism” (Heldke, 2003). Lisa Heldke (2003) offers culinary colonialism to critique how ethnic food remains largely exoticized in the American imaginary. In this framework, "food adventurers" (Heldke, 2003) act on colonial logics to use the food of the ethnic Other as resource for their own gain. Using culinary colonialism as a conceptual framework, I focus on the discursive and material impacts of these guides on Toronto's racialized immigrants and diaspora. According to scholars (Cook \& Harrison, 2003; Katz, 2001; Nash, 2002), there remains a critical need to contextualize discursive analysis within the materiality of broader processes like settler colonialism and global capitalism. Consequently, I propose that a close examination of these guides can provide a clearer sense of how colonial discourse and the material conditions of postcoloniality interlock to sustain legacies of colonialism in Toronto.

According to Saskia Sassen (1991), global cities are strategic units of analysis in an increasingly globalized world as they expose the inherent contradictions of world systems like capitalism and colonialism. By focusing on the city of Toronto as the scale of analysis, the main 
objective of this Major Research Paper is to examine the contradictory relationship between Toronto's discourse of food multiculturalism and culinary colonialism. This investigation will be guided by three main research questions. Firstly, how does the City of Toronto depend on culinary colonialism to market itself as the multicultural global city? Secondly, how does Tourism Toronto's “How to Eat...” guides help us better interrogate the contradictory connection between culinary colonialism and food multiculturalism? And lastly, how do these processes impact Toronto's racialized immigrants and diaspora? Through critical discourse analysis (henceforth CDA) of the HTE guides, I will demonstrate how Toronto's discourse of food multiculturalism re-articulates colonial assumptions that commodify racialized immigrants and diaspora as the Other. Thus, I argue that Toronto's global city strategy is critically linked to culinary colonialism. Furthermore, I aim to conceptually expand culinary colonialism by emphasizing food adventuring as a performative act of the Other. Within this context, I argue that the guides act as both a global ad as well as an intimate map for individual viewers to perform 'the Other' through food.

\section{Author's Point of Entry}

I would like to preface the following by locating my own personal position and consequently, my simultaneously personal and academic stake in this investigation. I engage with this discussion as a Korean Canadian woman with immigrant parents, a critical food scholar and a resident of Toronto. Within these intersecting identities, I have the privilege to theorize food as a productive artefact and take advantage of its profound ability to embody its historical, social and political surroundings. It is also due to this specific location that I find myself deeply 
uncomfortable with the current discourse on 'ethnic food' and cosmopolitan eating that circulates in the city of Toronto. This discourse largely posits that Toronto's robust ethnic food scene is evidence of its world-renowned multiculturalism and tolerance. As an extension of this logic, access to foods that were once deemed too stinky or too 'ethnic' on the shelves of large groceries stores is also seen as progress, something worth celebrating. This understanding of ethnic food is not exclusive to Toronto but has been circulating globally as cosmopolitanism is argued to be the “cultural habitus of globalisation" (Devadason, 2010, p.10). The logic of this dominant discourse seeps into the everyday of my life. For instance, it is commonplace for colleagues, friends and strangers to mention that they "love gimchi" when they realize that I am Korean. This affection for gimchi and in extension, my Koreanness, is supposed to be a compliment and a conversation starter. It is not. Instead, I am unsettled by how we have come to dominantly conceptualize and

eat ethnic food. As a result, this paper is an articulation of my own personal pursuit to understand this specific discomfort. The following discussion is for those who share this discomfort as well as the curiosity to understand it.

\section{A Postcolonial Food Lens: Theoretical Background}

Situating Toronto within the context of Canada's settler colonialism and global capitalism, this paper will use the theoretical parameters of postcolonialism to build on an emerging strand of postcolonial food studies. As an extension of postcolonialism, postcolonial food studies is an interdisciplinary discipline and theoretical project that does not prescribe a certain theoretical and/or methodological approach. As Leela Gandhi (2019) effectively notes, postcolonialism acts as a "meeting point and battleground" (p.3) of multiple disciplines and 
theories and is productively contested. However, there are major tenets that orient postcolonial work towards a discernible goal of decolonisation that will also frame this paper (Cook, 2008; Cook \& Harrison; Gandhi, 2019; Nash, 2002). Specifically, this paper is framed by Ian Cook and Michelle Harrison's (2003) discussion on the need to "re-materialize" (p.298) postcolonial work by re-shifting focus on both discourse and material culture. Cook and Harrison's work on "crossover foods" (p.296), meaning ethnic foods that cross over into mainstream culture, becomes a useful template as they point to food's capacity to scale-jump to address critiques of postcolonial work.

Postcolonialism operates with the fundamental acknowledgement that our current world is deeply shaped by the histories and legacies of European colonialism. Within this context, postcolonial critique points to the continued hegemony of Eurocentric discourse (e.g. Orientalism or modernism) to explain the persistence of colonial articulations of power in our current everyday (Cook, 2008; Gandhi, 2019; Hall, 1992; Said, 1978; Spivak, 2002; Razack, 2002). Colonial discourses not only served to rationalize and sustain colonization in the past but also continues to seep into common-sense understandings about ourselves, others and the world (Fanon, 1967; Hall, 1993; Said 1978). This centering of Eurocentric discourse is referred to as “epistemic violence" (Spivak, 1988) and has become a significant framework within the genealogy of postcolonial scholarship. According to Cooks and Harrison (2003), postcolonial scholarship responds in three main ways. First, postcolonial work challenges the dominance of colonial knowledge by centering the knowledge and narratives of the 'colonized'. Second, there is an emphasis on the messy and conflicting nature of seemingly fixed and neutral histories, categories, and identities. And thirdly, there is an interest in tracing the hybridity of these 
histories, categories and identities so that we can create new ways of knowing and being. Through these overarching orientations, postcolonialism is a "continuing process of resistance and reconstruction" (Ashcroft, Griffiths \& Tiffin, 2006, xxii). An inherent challenge to this pursuit is the issue of subjectivity. First raised in her seminal essay, "Can the Subaltern Speak?" (1988), Gayatri Spivak is concerned with the scholar's own complicity in reproducing the very relations of domination that they aim to critique. For Spivak, modern scholars who aim to address epistemic violence by speaking for "subaltern subjects", meaning the "lowest strata of the urban subproletariat" $(1988,25)$, fail violently by continuing the tradition of making objects out of historically colonized groups. For Spivak, such work is hardly liberating but rather a sneakier articulation of colonial knowledge production. Thus, Spivak warns the postcolonial scholar of their privilege as the knower because it inherently limits their ability to fully "touch the consciousness" of the known (1988, p.27).

However, postcolonialism has been met with notable critique: the scholarship is found to disproportionately focus on discourse and text at the expense of the material realities of postcolonial contexts (Cook \& Harrison, 2003; Nash, 2002; Katz, 2001). This neglect often results in the conceptual severing of postcolonialism and its very real counterpart, global capitalism. Global capitalism refers to "the contemporary state of capitalism, characterized by global structures of inequality; flows of capital, goods and people; and neoliberal governance" (Shankar and Cavanaugh, 2012, p.336). Global capitalism and political economy have been essential to postcolonial analysis since its inception as a discipline, as it is argued to be the enduring material articulation of European colonialism in our contemporary world (Ashcroft et al., 2006; Blunt \& McEwan, 2002; Blunt \& Wills, 2016; Dirlik, 1994). For instance, Alison 
Blunt and Jane Wills (2016) look to the historiography of geography to remind us that modern European empires were capitalist empires. The expansion of capitalism as a world system could not have happened without the "conquest and possession of other people's land and labour" (Jacobs, 1996, as cited in Blunt \& Wills, 2016, p.172). Thus, for Blunt and Wills, the history of modern European empires $i s$ the history of modern globalizing capitalism. In this regard, European colonialism was not only about the extraction of goods and wealth from its colonies but also a fundamental restructuring of them so that they could be progressively entangled in the webs of capitalism (Blunt \& Wills, 2016). Consequently, colonial discourse analysis that fails to acknowledge the material aspects of these interconnections also fails postcolonialism's initial impetus to decentre European discourse and reconstruct new ways of knowing. Instead, as Catherine Nash (2002) effectively sums:

Critics argue that postcolonialism is overgeneralizing and insensitive to the specificities of temporal and spatial contexts, that colonial discourse analysis drives a 'renewed interest in the texts of the west rather than their displacement; that postcolonialism locates all the world in the traumatic but ultimately progressive trajectory of western development. (Nash, 2002, 220)

To mediate such issues, Cook and Harrison (2003) turn to the realm of food to demonstrate the importance of material culture in postcolonial analysis. Cook and Harrison are not alone, as scholars are increasingly bridging the gap between food and postcolonial studies to examine the intrinsic connections between the material and discursive impacts of postcoloniality in localized contexts (see Duruz 2010, 2011, Duruz, Luckman \& Bishop, 2011; Saggar, 2018; 
Schwegler Castañer, 2018; Welsh 2018). By borrowing from food studies that have long established food as a critical embodiment of its cultural, economic, and political surroundings, scholars use food as a generative lens to examine the intimate everyday as well as broader global processes. What is useful in Cook and Harrison's work is their focus on the "scale-jumping" (2003, p.296) capacity of food. Scale-jumping looks at the "different scales of imperial and colonial processes and their geographies" (Nash, 2002, qtd in Cook \& Harrison, 2003, p.311) so that differences and similarities across postcolonial localities can be identified. As geographers, Cook and Harrison extend the discipline's notable emphasis on scale- jumping to examine why Caribbean food failed to cross-over into the UK mainstream. Food then becomes especially generative in postcolonialism because it operates as material articulations of these very complex interconnections. Inspired by Cook and Harrison's use of food to jump across different scales, this paper will further add to this body of scholarship by looking at Tourism Toronto's HTE guides. As these guides operate as both a global ad for the city as well as an individual map to material processes, they are useful in further highlighting food as a tool to scale-jump through the material conditions of postcoloniality.

\section{Toronto as 'Global City': Contextual Background}

In this section, I will situate Toronto as a "global city" (Sassen, 1991) and focus on the city's notable use of diversity to brand itself as a competitive global city. By exploring existing urban theory scholarship on global cities (Florida, 2003; Kipfer \& Keil, 2002; Sassen, 1991) and Toronto's particular history, I will emphasize the importance of discourses of food multiculturalism in Toronto's global city strategy. Following, I will briefly situate the socio- 
economic position of racialized immigrants and diaspora, who are central to Toronto's claim to operating as a global city.

According to Sassen (1991), global cities operate as "centers for servicing and financing international trade, investment and headquarters operations" (p.171). For Sassen, within the contemporary period of intensified economic globalisation and neoliberal capitalism, global cities like Toronto have become major actors in a "new geography of centrality" (1991, p.169). Within this new geography, global cities do not simply compete with one another but become "key nodes" (Sassen, 1991, p.171) in a spatialized network of global capitalism enabled by increasing deregulation and transnational migration. Consequently, these cities serve as productive sites of analysis in which major trends and contradictions of globalization materialize.

As the "world's most multicultural city", Toronto is currently positioned as a global city with the likes of major world centres like London, Paris, Hong Kong, and New York (Hamlin and Davies, 2016). Toronto is currently Canada's largest city, with a city population of almost 3 million and a city region population of over 6 million in 2018 (City of Toronto, 2018). It is also North America's second largest financial services centre (City of Toronto, 2018b). With more than half of its residents being foreign-born, Toronto is increasingly competitive in attracting global talent and investment (City of Toronto, 2018c). According to Hamlin and Davies (2016), Toronto is an example of a "new stratum of global cities" (p.186) that successfully emerged in the past half century. Toronto's emergence as a global city is owed to its economic conversion from an industrial port to a knowledge economy that started in the early 1970s. Along with this economic transition, Toronto critically benefitted from a shift in Canada's immigration policy 
that effectively bolstered and diversified its previously homogenous Western European workingclass demographic (Hamlin \& Davies, 2016, p.188). The policy targeted non-Europeans, who could fill both low-wage jobs as well as business and professional roles, who were crucial to the city’s "smart growth" (Teelucksingh, 2009). Toronto's conversion into a global hub for immigrants was further legitimized as Canada adopted multiculturalism as official policy in 1988. For Hamlin and Davies (2016), this change in demographics was crucial for Toronto to emerge as the global city in its current form. Consequently, racialized immigrants and diaspora have historically, and remain to be, central to Toronto's claim as a global city.

Toronto's global city strategy has been noted for its dependence on discourses of diversity and multiculturalism (Hackworth \& Rekers, 2005; Hamlin \& Davies, 2016; Kipfer \& Keil 2002; Kymlicka, 2004, 2010; McClinchey, 2008; Gunew, 1993, 1994, 2000). Considering food multiculturalism as an articulation of diversity through food, Tourism Toronto's HTE guides then become exemplary of how discourses of multiculturalism are used to market Toronto. Urban theorists have long established a strong connection between diversity and regional economic growth (Jacobs, 1996; Florida, 2003). Richard Florida's (2005) creative capital theory can provide deeper insight here. According to him, the 3Ts (tolerance, technology, and talent) are crucial for global cities to attract the world's "creative class" (2005). Global cities compete for the world's creative class, meaning technology and business innovators and creative professionals, as Florida argues that they are the major drivers of regional economic growth who enable cities to become 'global'. What is key to Florida's findings is that individuals are not simply driven to a city due to economic factors, but also to the degree of diversity and culture in the city. Thus, cities like Toronto depend on the effectiveness of discourses of multiculturalism 
in order to become a competitive global city (Hamlin \& Davies, 2016). Stefan Kipfer and Roger Keil (2002) would agree, as they argue that Toronto capitalizes on this very relation through it's "city of difference" approach. The city of difference strategy refers to a set of policies and discourses that centre culture and the aesthetics of diversity within urban development and promotion for global investment. For Kipfer and Keil (2002), Toronto's global city strategy hinges on using its specific location as the world's most ethnically diverse city to attract global talent, foreign investment, and migrants. Considering Tourism Toronto's use of food multiculturalism as an extension of this approach, these guides then serve a political and economic agenda to sustain Toronto as a thriving global city.

Despite the importance of diversity in Toronto's global city strategy, Toronto's racialized immigrants and diaspora increasingly face systemic socio-economic disadvantages. For instance, David Hulchanski (2011) looks at how these inequalities spatialize in the geography of the city over the span of 35 years, from 1970 to 2005 . According to him, Toronto is increasingly showing a trend of income polarity that can be evidenced through residential segregation. This process of income polarization visibly intersects with race and newcomer status. In his report, Hulchanski (2011) sections Toronto into three different "cities" based on individual income to show a pattern of neighbourhood polarization. City \#1 consists of high- income areas, located in the central city and close to the city's subway lines and the various services of a global city. In contrast, City \#3 consists of low-income areas that are found in the city's peripheries i.e. the inner suburbs, far from transit and services. In his study, visible minorities are disproportionately found (47\%) in City \#3 while they are explicitly lacking (11\%) in City \#1, which is predominantly white (82\%) (2011, p.11). Hulchanski also notes that immigrants are decreasing in City \#1 and increasing 
“dramatically” (2011, p.11) in City \#3. Although this alarming geography offered by Hulchanski may seem to conflict with representations of Toronto as a multicultural haven, Sassen (1991) would argue that such contradictions are what sustains global cities. In fact, Sassen emphasizes the tendency of global cities to spatialize the contradictions of intensified economic globalization. One major contradiction is the over-valorization of corporate capital and the devalorization of disadvantaged workers. Considering Hulchanski's findings, Toronto becomes another example of this troubling trend.

Lastly, as this paper focuses on discourses of food multiculturalism, the context of immigrant food insecurity in Toronto and Canada is useful. As immigrant food insecurity continues to be an urgent issue in Canada, a growing body of research focuses on the specific vulnerabilities of racialized immigrant individuals and households in their experience of food insecurity (see Maynard, Dean, Rodriguez, Sriranganathan, Qutub \& Kirkpatrick, 2019; Moffat, Mohammed \& Newbold, 2018; Koç, Soo \& Liu, 2016; Lessa \& Rocha, 2012 for more). In PROOF, an annual report of household food insecurity in Canada, Valerie Tarasuk, Andy Mitchell and Naomi Dachner (2016) define household food insecurity as "inadequate or insecure access to food because of financial constraints" (p.2). Consequently, food insecurity is conceptualized as a direct symptom of scarcity and financial instability. Immigrant food insecurity is increasingly becoming an urgent social and public health issue in Canada (Maynard et al., 2019; Tarasuk et al., 2016). In PROOF, new immigrants, defined as those who have been in Canada for less than five years, are found to be more vulnerable to food insecurity as their rate of household food insecurity (15.2\%) is significantly higher when compared to that of Canadianborn households (11.8\%) (Tarasuk et al., 2016). The rate of household food insecurity for 
immigrants who have been in Canada for more than five years is $12.0 \%$ (Tarasuk et al., 2016). Along with new immigrants, most racialized households are more prone to experience food insecurity. For instance, Black (29.4\%), Aboriginal (25.7\%) Arab and West Asian (16.8\%), South Asian (13.3\%), and Other or Multiple Origins (18.3\%) households all have higher rates than white households (10.4\%) (Tarasuk et al., 2016, p.25). East and Southeast Asian households have a rate of $10.3 \%$ (Tarasuk et al., 2016, p.25). This national trend is consistent in Toronto. According to the 2018 Who's Hungry Report, an annual profile of food insecurity in Toronto, newcomers, refugees and visible minorities are increasingly disproportionately represented in low income neighbourhoods and thus, vulnerable to food insecurity. The most recent report finds that there was a $4 \%$ increase in the share of food bank users in Toronto who are new immigrants (Daily Bread Food Bank, 2018 p.14). These rates of food insecurity serve to contextualize the following discussion, as the diversity that is so crucial to Toronto's global city strategy face increasing socio-economic disadvantages.

\section{Literature Review}

The purpose of this project is to interrogate the connections between how Toronto uses food multiculturalism to market itself as a global city and processes of culinary colonialism. Although there has been ample interest in these topics separately, there remains a gap in the literature that connects food multiculturalism and culinary colonialism, especially in a global city context. In the following section, I will explore the current scholarship that focuses on themes of culinary colonialism, food multiculturalism and performance theory to contextualize the following discourse analysis. 


\section{Culinary Colonialism}

"Culinary colonialism", or "cultural food colonialism" (Heldke, 2003), belongs to a rich body of literature that is critical of the asymmetric power dynamics that play out in the production, distribution, and consumption of food - especially ethnic food in post-colonial contexts. This dynamic is often referred to as "eating the Other", "Other-eating" or "exotic eating" and has been a major interest in postcolonial food scholarship (Cook, 2008; Duruz, 2010, 2011; Flowers \& Swan, 2012; Schwegler Castañer, 2018). "Eating the Other" was first coined by bell hooks (1992) in Eating the Other: Desire and Resistance and remains a seminal reference in this genealogy of work. In her article, hooks calls out the seemingly progressive act of consuming and commodifying racial difference as cultural appropriation. However, hooks' use of the term was strictly metaphorical as her critique concerned the arena of sex, desire, and pleasure and not food. hooks' term and critique were first applied in the study of food by food geographers David Bell and Gill Valentine (1995) and has been widely referenced ever since (for recent examples see Duruz, 2010; Flowers \& Swan, 2012; Schwegler Castañer, 2018). Within this body of literature, Heldke's cultural food colonialism has become an influential framework to conceptualize relations of power and domination that are enacted in the eating of ethnic food. For the purpose of this investigation, this framework is useful in understanding how and why Toronto engages with food multiculturalism as a marketing strategy. Furthermore, this framework contextualizes the impact of these processes.

In her book, Exotic Appetites, Heldke (2003) examines her own tendency to seek, eat and cook 'exotic' ethnic cuisines. She refers to this way of engaging with food as "food adventuring" 
(2003). Food adventurers are those "for whom eating is an expedition into the unknown, a pursuit of the strange" (Heldke, 2003, xxi) and are often "Euroamerican, Christian-raised persons for whom immigration is a (relatively) distant event" (Heldke, 2003, xxi). The counterpart of the white food adventurer is the food of "economically dominated" or "third world" (Heldke, 2003, xv) cultures, what we dominantly consider ethnic food ${ }^{2}$. It is notable that the very absence of the people to whom these various cultures belong is indicative of their lack of subjectivity within the food adventurer's imaginary. This absence of 'ethnic' people is exemplified in the given HTE guides and will be discussed later on.

Heldke argues food adventuring is intrinsically an extension of Western colonialism and must therefore conceptualized as a contemporary form of culinary colonialism. Culinary colonialism is defined as the "appropriation of [cultural food practices] by an economic or political power" (Heldke, 2003, xviii). What is key to Heldke's framework is that food adventuring comes at the expense of those who are read as 'ethnic'. This expense is both epistemic and material. Firstly, food adventuring reproduces Eurocentric categories of the Other by re-constructing essentialized categories of difference that are codified as 'ethnic'. These categories then motivate food adventurers to consume and appropriate desirable aspects of another's culture for their own gain. As a result, food adventuring reaffirms the colonial tradition of epistemic violence under the guise of well-intentioned curiosity and the pursuit for flavour. Secondly, food adventurers extract material benefits by accumulating cultural capital that cannot

\footnotetext{
${ }^{2}$ The hidden meanings of ethnic food have become a topic of increasing discussion that parallels its increasing use in food discourses. I borrow from Krishnendu Ray's discussion on the changing meanings of "the ethnic" in The Ethnic Restaurateur to define ethnic food as any food that belongs to people who are read as different and deviant i.e. the Other. Ethnic food acts as a seemingly "neutral" (Ray, 2016, p.4) codifier for foods that are racialized and seen as inferior.
} 
be accessed by racialized groups.

Postcolonial scholars have been critical of Heldke's (2003) culinary colonialism as her work is argued to reproduce the very categories she aims to critique (Cook, 2008; Duruz, 2010; Flowers and Swan, 2012; Narayan, 1997; Ray, 2016). Notably Uma Narayan (1997), using her location as a "third world feminist" (p.2), reminds Heldke of the risks of hinging critique of colonialism on the very colonial categories that she aims to challenge. For Narayan, Heldke's reproduction of essentialized categories leads her framework to grossly ignore the "complexities and paradoxes" (1997, p.64) that are abundant in eating another's food. Furthermore, Narayan argues that we must consider the Other's Other. Although culinary colonialism is surely a project of white supremacy, it is not only privy to white adventurers in America. In other words, food adventuring is not exclusive to the white middle class, as suggested by Heldke, but is a global hegemonic process that is internalized and enacted by racialized eaters as well. Narayan recalls her grandmother's "visceral repugnance for "beef eaters"” (1997, p.70) that applied to British colonizers as well as "fellow Indians" (1997, p.171) to point to the historical use of food to legitimize India's oppressive caste system. Narayan's critique is essential to this paper, as it points to how we are all implicated in broader systems of power and domination. By looking at culinary colonialism as a dominant global process, Narayan's critique expands culinary colonialism to better recognize how ethnically diverse post-colonial cities like Toronto can also be complicit in colonial eating projects.

To echo Narayan's poignant critique, more recent postcolonial work aims to complicate notions of Other-eating by focusing on the everyday interactions that occur "in-between" 
(Bhabha, 1994) binaries like 'us and them'. In this body of work, scholars highlight hybrid identities and encounters to show the inconsistencies of taken-for-granted assumptions in the Other-eating dynamic (Cook, 2008; Duruz, 2010, 2011; Flowers and Swan, 2012; Ray, 2016; Wise, 2011). Amanda Wise's (2011) investigation on everyday "gustatory commensality", meaning the act of coming together through food, in Australia is a good example. In her article, Wise explores the fieldwork of three research projects in Australia to highlight food courts as a key site of "everyday multiculturalism" (2011, p.82). By observing everyday encounters in food courts, she argues that inter-ethnic exchange is mediated by the particular space of consumption. For instance, Wise finds that food courts lack the formality of fixed 'ethnic' aesthetics that enable the food in food courts to "slide beneath the 'Otherness radar" (2011, p.88).

Consequently, in these sites of eating, eaters of diverse backgrounds partake in everyday multiculturalism through food without enacting processes of Other-eating.

Along with the site of the everyday, postcolonial scholarship also aims to address the issue of subjectivity by centering food narratives of migrants and diaspora when talking about ethnic food. Krishnendu Ray's Ethnic Restaurateur (2016) is a useful example of such work. In his book, Ray argues that the existing scholarship on ethnic fare remains disproportionately focused on the mainstream eater. Ray reverses this trope by centering the narratives of ethnic restaurateurs who negotiate notions of culinary authenticity and, more importantly, taste in their everyday. For Ray, ethnic cooks and entrepreneurs in America critically participate in defining notions of taste that circulate globally. Considering this form of immigrant agency, culinary colonialism as presented by Heldke can be expanded to be more critical of essentialized constructions of culture, ethnicity and race. 
Consequently, food demonstrates how seemingly fixed notions like culture, ethnicity and race are far more fluid and eating another's food is not always a colonial project. Within this body of literature, Australian postcolonial cultural theorist, Jean Duruz $(2004,2005,2010,2011)$ is a widely referenced source as her work highlights the messiness of dominant binaries to tell alternative narratives of Other-eating. For Duruz, the act of eating anOther's food is not always colonial and is key to contemporary post-colonial place- making. In Floating Food: Eating 'Asia' in Kitchens of the Diaspora, Duruz (2010) offers "floating food" to conceptualize this very capacity by mapping the food narrative of one James Maitland (pseudonym), a British-born university student, raised in Hong Kong as an expat with parents who now live in Singapore. Her aim is simple and important - to trouble the "mythic figure of the cosmopolitan (and its necessary "other")" (2010, p.46) as seen in most Other-eating scholarship. Floating food refers to how particular foods can embody hybrid types of identity and notions of home within the modern context of intense globalisation and postcoloniality. Within this framework, food becomes an "anchorage" (2010, p.29) to our increasingly "entangled cartographies of transnational belonging" (2010, p.49). For James, it is Otak-Otak, the Singaporean hawker dish that signals his longing for his ““'Asian” home” (2010, p.47). His sense of "Asian” home is constructed by his childhood memories in Hong Kong and visits to Singapore - note the lumpening of geographies. Thus, Duruz argues that categorizing James' cravings and memories of this dish as Other-eating misses the point. Duruz's analysis is effective in its aim to problematize the white villain-type cosmopolitan eater and its Other counterpart when conceptualizing culinary colonialism. However, as she admits herself, Duruz's analysis is significantly limited as her work once again privileges the perspective of a young white British 
male to talk about the "powers" (2010, p.47) (mythical or not) of ethnic food. A bigger note of concern is her failure to deeply engage with how broader systems of power like white supremacy, patriarchy, and colonialism interlock to change meanings of floating foods depending on one's particular social location. In her hopeful exploration that hinges on romanticising food adventuring, Duruz does not account for the ways in which individuals, despite their personal motivations, are implicated in larger projects of colonial eating. In simpler terms, although Duruz's account of James' individual story helps complicate culinary colonialism as a framework, it fails to disrupt it as a material process. Consequently, Duruz's exploration is limited in that it fails postcolonialism's major aim to actively resist colonial processes.

Duruz's (2010) failure to situate her findings of the everyday within a broader material context is symptomatic of a critical gap in the recent literature on Other-eating. Similar to Duruz, there are other works (e.g. Flowers \& Swan, 2012; Wise, 2011) that narrow analysis on ethnic food to the individual everyday scale to demonstrate the limitations of culinary colonialism. When looking at individual narratives, culinary colonialism may indeed be an insufficient framework as intensified globalisation and global capitalism encourages us all to be good cosmopolitan subjects with worldly experience. But what happens if we shift this analysis to a bigger scale -say the city level? Are processes of culinary colonialism obsolete? Heldke's (2003) culinary colonialism is first and foremost a structural analysis and is meant be applied at a scale of analysis that looks beyond individual narratives. Although her framework as presented in 2003 calls to be expanded, I argue that it remains a generative conception of broader eating projects that currently shape our world. Consequently, this paper aims to address this gap by 
applying Heldke's framework on the city-scale. What happens when a global city like Toronto depends on processes of culinary colonialism? How is Tourism Toronto's discourse of food multiculturalism connected to culinary colonialism? This investigation is especially useful because there is a lack of literature situated in the Toronto and Canadian context. The following section will first explore existing debates on food multiculturalism.

\section{Food Multiculturalism}

As food is increasingly used to evidence the cultural diversity and degree of multiculturalism of a given region, it is not surprising that Toronto, as the "world's most multicultural city", also partakes in this strategy to market its identity. Rick Flowers and Elaine Swan (2012) refer to this strategy as "food multiculturalism" and define it as "the ways in which educational policy makers, the tourist industry, government, and media promulgate the idea that by eating ethnic food we can learn about ourselves, the Other and their culture" (p.1).

Consequently, food is used as a "public pedagogy of multiculturalism" (Flowers \& Swan, 2012, p.1) so that a certain city or region is seen as more tolerant when it has a diverse and celebrated ethnic food scene.

Flowers and Swan (2012) were not the first to identify the prominent role of food within the discourse and practice of multiculturalism. In fact, scholars have developed various terms to describe this strategy, such as Ghassan Hage’s (1997) “cosmo-multiculturalism”, Yasmin Alibhai-Brown's (2000) “3S (samosas, steel drums, and saris) model of multiculturalism” or Sam Grey and Lenore Newman's (2018) “gastronomic multiculturalism”. The existing scholarship on 
food multiculturalism is mainly critical as the failures of food multiculturalism are argued to largely mirror that of liberal multiculturalism (Alibhai-Brown, 2000; Duruz, 2010; Flowers \& Swan, 2012; Grey and Newman, 2018; Gunew, 1993; Hage, 1997). For Grey and Newman (2018) liberal multiculturalism refers to an ideology and a set of policies that point to the recognition of minority cultures as the remedy to structural inequality. In the context of food, this political ideology materializes as the acceptance of minority cuisines within a national food culture, what Grey and Newman call "gastronomic multiculturalism" (2018, p.718). Gastronomic multiculturalism, as a specific articulation of liberal multiculturalism, acts to further reinforce Eurocentric categories of difference under the guise of liberalism. Furthermore, it detracts from a critical recognition that structural inequalities cannot be solved by a "politics of recognition" (Grey \& Newman, 2018, p.718). What is especially useful in their article is that Grey and Newman extend their critique by connecting processes of gastronomic multiculturalism to their own concept of "culinary colonialism"3. By exposing the inherent contradictions between liberal multiculturalism and indigenous food sovereignty, they argue that gastronomic multiculturalism operates as the "justification" (2018, p.720) for culinary colonialism. However, in their poignant analysis, Grey and Newman purposefully exclude immigrants. In their discussion, immigrants are conceived to benefit from processes of gastronomic multiculturalism. Although equating indigenous and immigrant groups is violently problematic, which is precisely the crime as Grey and Newman point out, I argue that there are productive parallels. Both groups are subordinated under the realities of global capitalism as well as Canada's settler colonialism. Noting this parallel, I argue that there are critical points of converging issues and thus, interests when

\footnotetext{
${ }^{3}$ Grey and Newman (2018) conceptualize their own "culinary colonialism" that considers the "irreducible territorial dimensions" (p.719) of indigenous food sovereignty. They define culinary colonialism as the "extension of Settler jurisdiction over, and exploitation of, Indigenous gastronomy" (p.719). Their culinary colonialism" is conceptually distinct from Heldke's culinary colonialism.
} 
considering indigenous and immigrant context in Canada. Consequently, in this paper, I aim to expand Grey and Newman's argument to include racialized immigrant and diasporic groups. By focusing on the HTE guides, I can examine how Tourism Toronto enacts material processes of culinary colonialism at the expense of the city's racialized immigrants and diaspora. Consequently, I can then examine how processes of culinary colonialism not only impact indigenous groups but also immigrants and diaspora.

What is especially useful in Flowers and Swan's (2012) discussion is that they distinguish between food as a pedagogy of "official multiculturalism" and a public pedagogy of "everyday multiculturalism". Official multiculturalism refers to policy on multiculturalism while everyday multiculturalism refers to "intercultural encounters that take place in day-to-day happenings at work, in the family or on the street" (Flowers \& Swan, 2012, p.3). In their paper, Flowers and Swan focus on the latter by presenting the "culinary biography interview" (2012, p.12) of Frank (pseudonym). Frank is an Anglo-Australian male who has been in two inter-racial marriages and has lived in Kenya, Tanzania, and Indonesia as an expatriate. Inspired from Duruz's (2010) “entangled cartographies”, Flower and Swan select Frank as the ideal candidate to show how complicated personal geographies can be. However, due to their narrow focus and arguably problematic choice in subject, Flowers and Swan's analysis is limited as it only goes insofar as to complicate the "neat categories" $(2012$, p.26) in Other-eating literature. Furthermore, this troubling of category only concerns the role of the food adventurer. Flowers and Swan continue to privilege the perspective of the white eater while leaving out its dreaded counterpart - the Other. 
In contrast, this paper looks at processes of food multiculturalism, not as experienced by privileged white males but as a marketing strategy by and for the city. As the HTE guides are published by Tourism Toronto, the official tourism website funded partly by the City of Toronto, they are an example of Toronto's official multiculturalism. Within this context, I can examine how Toronto depends on a discourse of food multiculturalism to brand itself as a global city in an international arena. More importantly, I am able to interrogate how this global city strategy is connected to culinary colonialism. Furthermore, through these guides, I can also focus on the spaces in between official and everyday multiculturalism. The given HTE guides are circulated by Tourism Toronto's website and are consumed at the individual level. Thus, the analysis of these guides takes place in both the macro level (city/ global) and micro level (individual viewer/eater). This multi-planed analysis will provide a better understanding of how individual eaters are implicated in broader processes of culinary colonialism, regardless of well-intended motivations. In addition, by situating the investigation in both the city/global level and the individual level, I can effectively scale-jump through these guides to examine its multifaceted impacts.

\section{Race and Ethnicity in Performance Theory}

In this last section, I will draw on the existing literature on performance theory that applies to race and ethnic identity. By borrowing from this body of scholarship, I aim to conceptually build on Heldke's culinary colonialism by emphasizing categories like race, ethnicity, and Otherness as performative. In this context, I point to food and eating as a pivotal means to performance. Through the critical discourse analysis of the guides, I will demonstrate 
how the HTE guides operate on the micro-level as a map for individual eaters to arrive at their final destination- to perform the Other through food.

When conceptualizing race and ethnicity as performative, performance theory points to how race and ethnicity, like gender, are socially constructed and thus, more fluid than assumed (Butler, 1990; Clammer, 2015; Salih, 2007; Schechner, 2013). With this point of entry, performance theory looks at how racial and ethnic identity are not only assigned but also affirmed and thus, 'acted' out in the everyday. Within the literature of performativity, Judith Butler's $(1990,1993)$ work on gender, sex and sexuality remains a seminal reference as she has provided foundational concepts when thinking about the performativity of social constructs. In Gender Trouble, Butler (1990) introduces the idea of performativity by arguing that, "gender proves to be performance - that is, constituting the identity is it is purported to be. In this sense, gender is always a doing, though not a doing by a subject who might be said to pre-exist the deed" (p.25). When considering performativity, Butler is especially interested in how discourses produce categories like gender and argues that there is no identity that precedes discourse. What is key to Butler's conception is that when we consider gender as performative, we can start to examine how seemingly fixed and unrelenting categories have always been far more unstable. This renders critical moments for us to expose and subvert categories by exposing its very "factitiousness (i.e. its constructedness) rather than its facticity (i.e. the fact of its existence)" (Salih, 2007, p.55). In Bodies That Matter, Butler (1993) refers to this process as "re-citation" which can be useful in examining our given guides. For instance, when considering the instructions in the HTE guides as re-citations of the Other's way of eating, we can observe how 
categories like race and ethnicity are hardly fixed but constantly reaffirmed through mechanisms like the guides.

Butler's interpretations of performativity have been increasingly extended to think about race and ethnicity (Clammer, 2015; Schechner, 2013), as Butler herself admits that race is another "regulatory regime" (Butler as cited in Salih, 2007, p.63) that can benefit from performance theory ${ }^{4}$. For example, John Clammer (2015) suggests that by examining the performativity of race and ethnicity, we can extend the productivity of this approach to disrupt dominant processes of racialization. Clammer calls for further development in this scholarship as he suggests some orientations for future works. According to Clammer, by connecting the study of race and ethnicity to developments in performance theory and the study of religion and the body, we may arrive at "liberating possibilities" (2015, p.2164). To build on this suggestion, I present food as another productive site of analysis; food has long been established as a key means to perform race and ethnicity (Cook, 2008; Duruz 2010; Koç \& Welsh, 2001; Lessa \& Rocha, 2012; Slocum, 2011). In the case of this investigation, I am more interested in interrogating how food can be used to perform anOther's race and ethnicity as instructed by the guides. Consequently, this analysis will add to the existing scholarship by not only focusing on food but also looking at how performances can be appropriated and commodified.

\footnotetext{
${ }^{4}$ Some scholars like caution the equating of race with gender, sex, and sexuality because there are foundational differences that must be acknowledged (Gates,1993; Salih, 2007). For instance, Henry Louis Gates Jr. (1993) poignantly reminds us that gender, sex and sexuality do not present, nor are read, the same way as race.
} 


\section{Critical Discourse Analysis: Methodology}

The given investigation will use critical discourse analysis (CDA) to closely examine Tourism Toronto's HTE guide. Using this guide as a case study, I aim to demonstrate how Toronto's use of food multiculturalism as a global city strategy enacts material processes culinary colonialism. Within the framework of CDA, Tourism Toronto's HTE guides are an example of texts that aim to represent Toronto as a multicultural city through food. These texts contribute to a discourse that legitimizes Toronto's claim to global city status. Consequently, this representation of Toronto serves a specific agenda to attract tourists, global talent, and foreign investment. By analyzing the HTE guides, I can expose the underlying meanings and implications of Toronto's discourse of food multiculturalism. Specifically, I am interested in how the HTE guides produce and legitimize a set of colonial assumptions and actions surrounding ethnic food that materially impact Toronto's racialized immigrants and diaspora.

CDA refers to a type of discourse analysis that interrogates "the way social power, abuse, dominance and inequality are enacted, reproduced and resisted by text and talk in the social and political context" (van Dijk, 2001, p.352). For Teun van Dijk (2001), CDA is first and foremost a productive perspective rather than a prescription of methodology, as the objective of CDA is to expose and resist social inequality. CDA is able to attain this aim by conceptualizing discourse as a central mode to knowledge production and thus, power. Cultural theorist Stuart Hall's (1992) discussion on discourse and power can be useful here. In The West and the Rest, Hall (1992) borrows from Foucault's theory on discourse to demonstrate how Orientalism was central to 
European colonialism. This is because discourse, knowledge, and power are intrinsically related. Discourse is "a way of talking about or representing something" (Hall, 1992, p.225) that informs social perception and practice. For Hall, discourse is about the production of knowledge through language. Within this context, whoever has access to produce, shape or employ a discourse also holds the power to make certain statements 'true' or 'false'. This form of knowledge production or meaning making becomes a critical mode of power as every social practice has a discursive element. Thus, the power of discourse comes from its ability to materialize through social practice i.e. action. Considering this notion of discourse, $\mathrm{CDA}$ is interested in how discourses are inherently socio-politically situated and thus, can act as strategic tools of control, dominance, and inequality. As discourse exists through language, CDA uses language to analyze the interests and logics that underlie a particular text. In the case of this investigation, by analyzing how language is deployed by the city to represent ethnic food, I can also show how these statements legitimize a set of assumptions and actions. Although discourse cannot be reduced to statements that only serve the interests of the dominant class, it plays a significant role in materializing the interests of the powerful. This conceptualization of discourse underpins the methodology of this paper. As Hall points to the necessity of Orientalism as a discourse in European colonialism, I have emphasized the importance of Toronto's discourse of food multiculturalism in its global city strategy. By looking to the guides as a strategic cross-section of this discourse, I aim to expose how it is intrinsically linked to the material practices of culinary colonialism.

With its emphasis on the power of discourse, CDA as a methodology is in accordance with the theoretical parameters and objectives of this paper. As aforementioned, postcolonialism identifies the dominance of Eurocentric discourse as a major driving force of the Eurocolonizing 
project. Thus, a methodology that systematically interrogates the underlying assumptions that make a discourse effective is crucial to postcolonialism's aim of exposing and resisting colonial discourses. Furthermore, CDA also includes the examination of subject positions to interrogate the power dynamics that are enacted through discourse.

This paper will use Tourism Toronto's "How to Eat..." guides as a case study to examine Toronto's discourse of food multiculturalism. The series of five infographics have been selected for a number of reasons. Firstly, these guides are created and circulated by Tourism Toronto, the official tourism organization for the city of Toronto. Thus, they are textual examples of how the city is actively constructed by a discourse of food multiculturalism. Secondly, returning to Flower and Swan's (2012) framework on food multiculturalism, these guides are examples of how Toronto uses food as a pedagogy of official multiculturalism (as a global advertisement) as well as everyday multiculturalism (as a guide for individuals). By using text that straddles both domains, I am able to examine how they are connected. Lastly, as 'how to eat' guides, these guides are especially useful in demonstrating the role of discourse in shaping action. By dissecting the assumptions that underlie these instructions, I can demonstrate how these guides enact material processes of culinary colonialism when employing discourses of food multiculturalism. Due to these reasons, the scope of this paper is strategically limited to the analysis of these particular HTE guides. A more extensive analysis based on more and diverse texts can be useful in the future.

The CDA of these particular guides focused on keywords and the ways in which language was used to represent eating ethnic food through the practice of open coding. Open 
coding refers to the process of identifying relevant concepts in texts (Creswell, 2003). It entailed a systematic process of: (1) transcribing the text (images are not included in the given analysis); (2) open coding; (3) creating categories; and (4) synthesizing core categories/themes in the guides (Creswell, 2013). By placing these themes within the theoretical context of postcolonialism and the conceptual framework of culinary colonialism, I explored the implications of these guides at both the city and individual level.

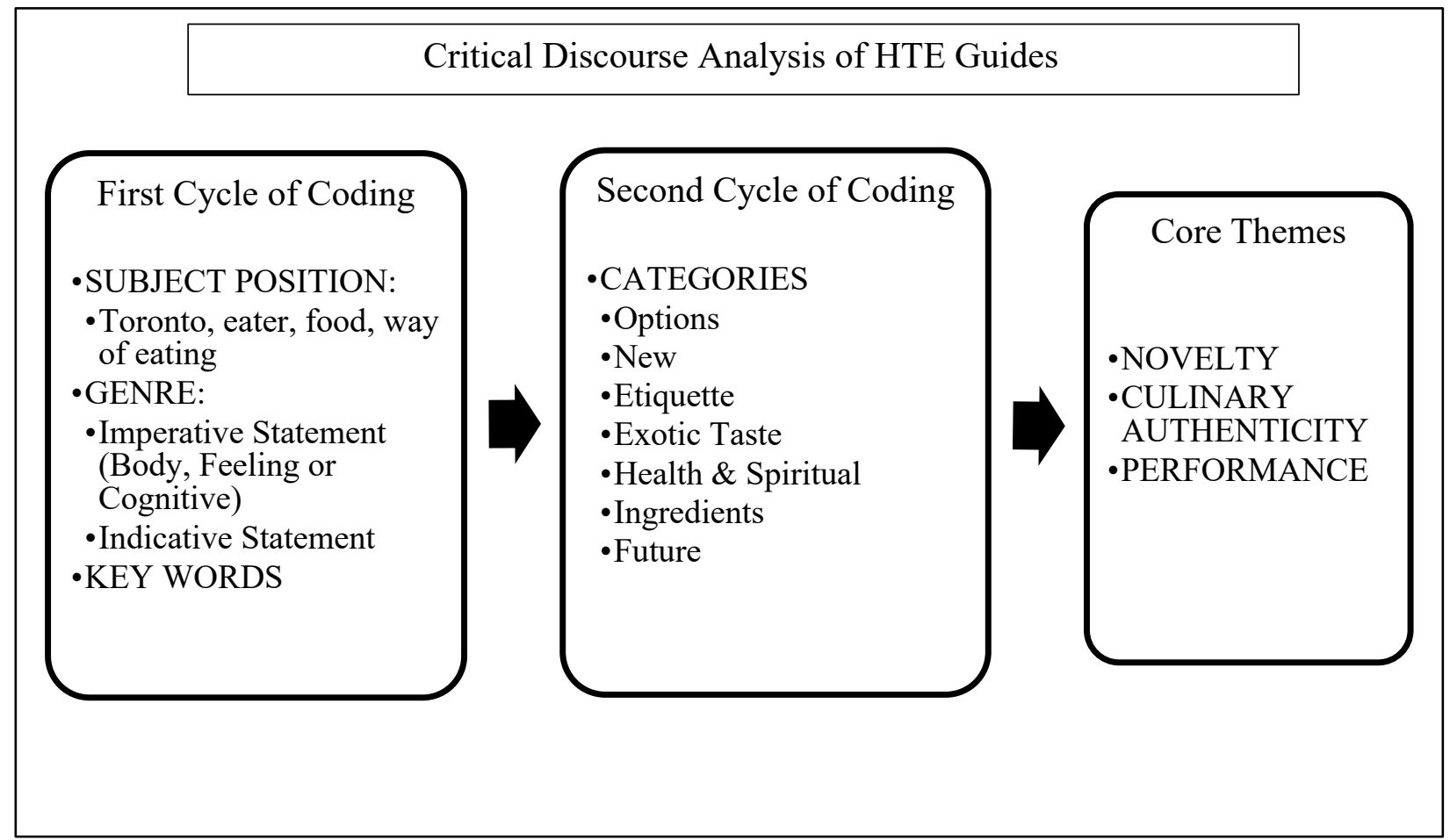

Figure 1. Critical Discourse Analysis of HTE Guides. This figure outlines the major steps in the critical discourse analysis of Tourism Toronto's HTE guides. 
This particular study conducted two main "cycles" (Saldana, 2015) of coding to arrive at core themes found in the texts (see Figure 1). The first cycle of coding focused on four elements: (1) subject position in text (City of Toronto, eater, food, way of eating); (2) genre of text (imperative statements pertaining to the body, feeling or cognition or indicative statements); and (3) key words. The second cycle of coding consisted of conceptualizing thematic categories by collapsing the information derived from the first cycle. This process involves "classifying, prioritizing, integrating, synthesizing, abstracting, conceptualizing, and theory-building" (Saldana, 2015). In the second cycle of coding, I used thematic categories: options; new; etiquette $^{5}$; exotic taste ${ }^{6}$; health $\&$ spiritual; ingredients; and future, to further analyze the text of the guides. Through the second cycle of coding, I arrived at three core themes: (1) Novelty; (2) Culinary Authenticity; and (3) Performance. These themes largely correspond to themes around culinary colonialism as discussed by Heldke. Findings from the guides also conceptually expand Heldke's framework by emphasizing the theme of performance. The following discussion will be organized around these three themes to demonstrate how discourses of food multiculturalism, as employed by Tourism Toronto's HTE guides, are intrinsically linked to processes of culinary colonialism.

\section{Discussion}

\section{Novelty}

\footnotetext{
${ }^{5}$ Etiquette consists of instructions regarding a specific way of eating, order of eating and utensils.

${ }^{6}$ Exotic taste refers to any text that presents food as "strikingly or excitingly unusual or different" (Heldke, 2003, p.18).
} 
A core theme found in the HTE guides is novelty. In this analysis, novelty refers to the characteristic of being new and consequently, different and exotic. The guides consistently present the eating of ethnic foods as a new and unfamiliar experience, as seen in the quote below:

Use the ginger served alongside the sushi to reset your mouth between rolls. Not only is it a digestive aid, but it helps prepare your mouth for a totally different, totally delicious new flavour. (Tourism Toronto, 2019, emphasis added)

It is due to the foods' newness that they are conceived as desirable and delicious. This can be seen in the texts that are coded as "new", "options", "exotic taste", and "health \& spiritual" (see Figure 1). The theme of novelty is also evidenced by the very nature of these guides, as their initial purpose is to educate viewers on how to engage with new and "intimidating" foods. Considering the framework of culinary colonialism, this is not surprising; Heldke states that the food adventurer's journey is essentially a "quest for novelty" (2003, p.9). Within this quest, 'novel', 'ethnic', and 'exotic' are "somehow synonymous” (Heldke, 2003, p.13) and thus, ethnic food is positioned as the "unknown territory" (Heldke, 2003, p.12) waiting to be discovered by food adventurers.

Within postcolonialism, this construction of ethnic food is problematic for several reasons. Firstly, defining ethnic food as novel assumes that certain ethnicities, i.e. racialized ones, are positioned in the peripheries of what is considered normative. This is a critical colonial mechanism in Eurocentric discourse that rigorously privileges whiteness as the norm. Consequently, this definition of ethnic food reaffirms colonial categories of the Other by 
asserting that the cultures of certain ethnicities are naturally novel, exotic, and discoverable. In this context, ethnic means different and more importantly, as Ray (2016) poignantly argues, ethnic means race. For Ray, the term 'ethnic' has become "a dominant mode of framing difference without falling into the problem of race" (2016, p.4). It is important to highlight the connections between ethnicity and its more threatening counterpart, race, as the logics of ethnicity and ethnic food operate with race to mark coloured bodies and by extension, their food, as different and thus, un/desirable. The HTE guides actively illustrate this definition of ethnic food as the five 'ethnic' foods that are showcased in the guides are Japanese, Mexican, Ethiopian, and Vietnamese. By depending and reaffirming this notion of ethnic food, the guides attest to how Toronto's discourse of food multiculturalism depend on colonial assumptions to be coherent.

Secondly, the problem with novelty, as Heldke (2003) argues, is that it runs out. Novelty, by definition, is temporary. Consequently, by conceptualizing ethnic food as novel, these guides also legitimize eaters to treaters ethnic food as expendable cultural accessories. They are no longer aspects of a complex and full culture with a historical and political context. The guides' emphasis on numerous and diverse options further present ethnic food as a never-ending source of exotic enjoyment available to the food adventurer. For example:

The variety of stews are endless, so get ready to get hooked on sampling different types and finding your favourite. (Tourism Toronto, 2019, emphasis added) 
For Heldke, when we define ethnic food as novel, it becomes a means to cultural capital i.e. social distinction, for food adventurers. Eaters chase novelty through ethnic food, as it enhances their capacity to perform and claim an exclusive type of knowledge that is valorised within an increasingly globalized capitalist world. This process is referred to as cosmopolitan eating or culinary cosmopolitanism and is critically connected to culinary colonialism (see Cappeliez \& Johnston, 2013 for more). Through the performance of exclusive food knowledge and practices, food adventurers gain a level of social distinction by tapping into the logics of culinary cosmopolitanism. What calls to be acknowledged is that this process does not equally apply to racialized immigrants who have been eating and cooking these ethnic foods long before any food adventurer. Instead, racialized immigrants and their cultures are largely seen as resources for food adventuring. Here, it is worth reminding that food adventuring is not exclusive to white eaters. In fact, we have discussed the need to conceptualize culinary colonialism as a dominant process that is enacted by racialized individuals as well. Similarly, the given guides are not exclusively consumed or actualized by white viewers. I argue that this does not conflict with the merits of culinary colonialism and instead reaffirms the hegemonic nature of this process. What is important is that the foods of racialized ethnicities are dominantly seen as novel and exotic while that of Anglo-European ethnicities are seen as normative. This asymmetric construction acts as the crux of how Eurocentric discourse becomes material domination.

Although Heldke (2003) uses cultural capital to explain the motivations of individual food adventurers, her analysis can be applied at the city level. As aforementioned, cultural capital is especially important for Toronto to sustain its status as a global city. Tourism Toronto uses discourses of food multiculturalism to signal to the city's cultural capital. However, by 
using Toronto's racialized immigrants and diaspora as resources in this discourse, these guides are actively complicit in processes of city-level food adventuring.

\section{Culinary Authenticity}

The HTE guides also centre a theme of culinary authenticity by pointing the viewer to the "right" or "proper" way of eating. This theme consists of text that were coded as "etiquette", "ingredients", "health \& spiritual", and "indicative statements". Whenever the guides describe the food or prescribe a particular way of eating, they actively construct and legitimate a particular understanding of culinary authenticity around the given food items. For example:

Ramen isn't the watery broth you make out of a packet when you have a cold, it's a full noodle experience that requires proper utensils. (Tourism Toronto, 2019)

Heldke (2003) highlights the importance of culinary authenticity in culinary colonialism. Food adventurers seek not only the novel and the exotic in food, but also an authentic experience. For her, culinary authenticity operates as code for a variety of elements such as novelty, replicability, and nativity. All of these elements shape the expectations of what ethnic food should be for the food adventurer i.e. their expectations. What is useful in her analysis is that she argues that the “confused and confusing" (Heldke, 2003, p.24) meanings of authenticity all interact to legitimate or delegitimate foods and ways of eating. Within this context, culinary authenticity is useful to examine issues of subjectivity and power. 
Subjectivity has long been used to observe power relations in postcolonial scholarship. For Gayatri Spivak (1988), subjectivity concerns the ability to truly speak for oneself. In the given investigation, I am interested in who is privileged to define authenticity and who are these guides for? In the first cycle of coding, I examined the various subject positions in the texts to find four rotating subjects: the City of Toronto (as the voice of the guides); the eater (the viewer of the guides); the food; and the way of eating. There is no mention of immigrants, diaspora or 'ethnics' except when the guides are contextualized as instructions to "eat like a pro". Evidently, the guides privilege the voice of Tourism Toronto to define authenticity for the five food items on behalf of the city's immigrants and diaspora. This effectively prevents any meaningful opportunity for members of the given ethnic communities to provide their own specific understandings of culinary authenticity. Furthermore, the guides present the foods and thus, cultures of these ethnicities as fixed - immediately accessible and consumable. This can be evidenced through the guides consistent use of indicative statements that act to essentialize the given food items. For instance:

Banh Hoi are tasty rice noodles that are compressed into a square sheet, like a piece of cheesecloth. They're difficult to make and are usually saved for big celebrations. (Tourism Toronto, 2019)

When considering these guides as an ad for Toronto's global city strategy, Tourism Toronto as the voice of authority in defining culinary authenticity is especially problematic. This is because these guides demonstrate how discourses of food multiculturalism act to essentialize and commodify the racialized Other to serve the interest of the city, and other elite stakeholders who 
benefit from Toronto's global city status. In this regard, racialized immigrants and diaspora have become commodified resources for the city to sustain its status as a global city. Heldke (2003) also makes note of this tendency by outlining the ways in which food adventuring depends on exploiting the ethnic Other and their culture as "raw material" (xvi). What is especially problematic is that this violent process is often invisible since the Other as resource is such a normalized concept within Western colonial ideology.

In the HTE guides, eaters are also reassured that the outlined ways of eating are authentic. For instance, in the ramen infographic, readers are told to "slurp away" and to not be “afraid" of making noise (Tourism Toronto, 2019). These reassurances have two major implications. First, it tells me that these guides were written for outsiders. The white blonde boy who is depicted as the eater in the guides is also a telling clue. Secondly, these instructions operate under the Eurocentric assumptions on food etiquette that deem anOther's way of eating as deviant and worth reassuring. It is especially conflicting to see that the guides actively reassure the food adventurer to claim these 'authentic' ways of eating when racialized immigrants are still subject to "segregation, jokes, shame and discrimination" (Lessa \& Rocha, 2012, p. 195) when practicing these very same ways of eating.

\section{Eat like a Pro: Performing the Other}

The last theme that will be the focus of this discussion is performance. Performance concerns the material individual implications of these guides by observing the imperative statements that instruct the eater's body, feeling and cognition to "eat like a pro". By adopting developments in performance theory to Heldke's (2003) culinary colonialism, I hope to further 
expand this framework by conceptualizing eating as a means to performing anOther's race and ethnicity.

What is notable in these particular guides is their propensity to extend instruction beyond bodily action to feeling and cognition. In the analysis, instructions to "daydream of the next bowl" or to "plan your next injera session" were coded as "cognitive imperatives" while instructions to "not feel afraid" and "enjoy the broth" were coded as "feeling imperatives". Through these instructions, these guides generously map out directions towards the food adventurer's final destination - to eat like them. Heldke also writes about the critical role of food writing, that includes restaurant reviews, food shows, articles and guides, in the culture of culinary colonialism. According to Heldke (2003), food writing on ethnic food becomes a key tool to bridge the "separation between the consuming Western self and the consumable Other" (p.61). By “including countless maps, charts and tables, and information" (2003, p.64), food writing such as these guides operate as maps for food adventurers to eat their way into culinary colonialism.

Understandably, Heldke (2003) is highly critical of most food writing on ethnic food as she considers it a contemporary colonial mechanism to know and claim the ethnic Other. For her, the increasingly robust food writing industry responds to the food adventurer's relentless "Cartesian desire" (2003, p.63) to attain more and more exclusive knowledge about the Other. The result of such writing is that it further marginalizes racialized immigrants and diaspora by reaffirming an apolitical and ahistorical understanding of their culture and them. She argues: 
The dining guide, like the tourist guide, is "on the side of amnesia"... obliterating the events by which the ethnic Other became available to the Western diner. These others become unreal, static archetypes whose cooking remains unchanged for centuries. (Heldke, 2003, p.67)

Although Heldke's critique of food writing remains useful when considering the given guides, I argue that these particular guides highlight the role of performance in food adventuring. By borrowing from performance theory to re-conceptualize 'eating the Other' to 'eating like the Other', I can conceptually expand culinary colonialism. As aforementioned, when we conceptualize categories like race and ethnicity as performative, we are able to disrupt the assumption that they are immutable and natural. Instead, these categories exist through and by the legitimation of discourse and action. Categories of the ethnic Other then also exist through and by discourses like food multiculturalism and actions like food adventuring. Within this framework, these guides are examples of maps to a particular performance - eating like the Other.

Conceptualizing food adventuring as a performance of the Other is especially useful since an essential aspect of food adventuring is maintaining an outsider status "with an in" (Heldke, 2003, p.55). As Heldke (2003) poignantly states, "as a food adventurer, I seek only to act as if I were a member of the culture of the Other. The Other must remain, ultimately, Other" (p.67). Although Heldke briefly compares food adventuring as an "act", she does not go deeper to consider food adventuring as performative. In fact, a key critique of Heldke's discussion, as discussed previously, is her depiction of categories like culture, ethnicity and race as fixed. By 
further emphasizing the role of performance within culinary colonialism, I can effectively expand this framework in two meaningful ways. Firstly, when considering these guides as a map to performance, we can examine how dominant discourses (such as discourses of food multiculturalism) are constantly reaffirmed into action by powerful actors like the city and the tourism industry. In the previous section, I have explored how discourses of food multiculturalism as instigated by Tourism Toronto have two main implications: (1) reaffirms Toronto as a global city and (2) initiates city and individual level actions of food adventuring. By exposing the underlying colonial assumptions of this discourse, I can display the connections between discourses of food multiculturalism and the materiality of culinary colonialism. Furthermore, I can show how Toronto depends on processes of culinary colonialism to sustain its status as a global city. Secondly, I am able to conceptually build on Heldke's culinary colonialism by emphasizing race and ethnicity as performative categories rather than fixed ones. Food adventuring is not about becoming the Other through food but is fundamentally a performance of the Other. This Otherness is constantly contested, constructed, and re-cited by maps like these guides.

\section{Conclusion}

Global cities are strategic sites of inquiry; they spatialize contradictions of global capitalism that exacerbate global inequalities and legacies of colonialism (Sassen, 1991). In this regard, global cities prove to be especially useful in postcolonial scholarship and this paper. The main objective of this Major Research Paper was to demonstrate the insidious connections between Toronto's discourse of food multiculturalism and material processes of culinary colonialism. In the context of intensified global capitalism, discourses of food multiculturalism 
are increasingly used to legitimize the tolerance of global cities to attract foreign investment and migrants. By reviewing existing literature on global cities as well as Toronto's historical context, I have explored how food multiculturalism plays a key role in Toronto's global city strategy. Following, I explored recent debates in postcolonial food scholarship that uses food, especially ethnic food, to "re-materialize" (Cook \& Harrison, 2003) postcolonial analysis focused on discourse. Within these parameters, I investigated how Toronto's seemingly progressive discourse of food multiculturalism is underpinned by colonial assumptions that commodify its racialized immigrants and diaspora as the Other. In order to interrogate this contradiction, I used Heldke's (2003) culinary colonialism as a framework to examine Tourism Toronto's "How to Eat..." guides. These guides were selected as a productive example of how discourses of food multiculturalism are used to legitimize Toronto's claim to global city status. Through critical discourse analysis, I demonstrated how these guides depend on colonial assumptions to articulate notions of food multiculturalism. Most notably, Toronto's racialized immigrants and diaspora are critically absent in these guides and instead rendered as resources for the eater. Consequently, Toronto's global city strategy was found to be linked to culinary colonialism. Furthermore, by adopting performance theory within culinary colonialism, I argued that the guides also act as maps for individual eaters to arrive at their desired destination- to eat like Them. Considering food adventuring as a performance of the Other opens up meaningful opportunities to expand Heldke's (2003) culinary colonialism. When food adventuring is conceptualized as 'eating like the Other', I emphasize that categories like culture, ethnicity and the Other are fundamentally constructed and reaffirmed through discourse and action. In this context, culinary colonialism no longer reproduces colonial categories but can act as a generative framework for postcolonial 
food scholarship to expose and disrupt colonial eating projects that hide under seductive mechanisms like multiculturalism.

\section{Towards Anticolonial Eating}

The questions that motivate this research project are by no means fully answered. Instead, I hope that my work can contribute to a growing body of research that aims to actively expose the critical contradictions that feed global cities, especially through the use of food. One particular orientation for future works is further developing what Heldke (2003) refers to as "anticolonial eating". In her conclusion, Heldke optimistically claims that there is an opportunity

for food adventurers to eat ethnic food without being colonial. Her suggestion largely involves a call to food adventurers to practice a deeper appreciation for ethnic food and its cultural traditions. However, Heldke's anticolonial eating has been met with notable critique (Cook, 2008; Flowers and Swan, 2012; Narayan, 1997; Ray, 2016) as her suggestion also fails to consider the very real material conditions of postcoloniality. However, I am not convinced that we should give up on anticolonial eating as a whole. Instead, I conclude this paper by suggesting that future works on this topic should explore possibilities for anticolonial eating by focusing on the lived experiences and knowledges of racialized immigrants and diaspora. 
Appendix A

The following table demonstrates the process of critical discourse analysis of Tourism Toronto's HTE guides. All the text in the guides were first transcribed in the first column titled "Text". The first cycle of coding looked for: subject position (Toronto, eater, food); genre (imperative (body, feeling or cognitive) or indicative statement); and key words. The second cycle coded for the following categories: options; new; etiquette; exotic taste; health \& spiritual; ingredients; future. Through these two cycles of coding I arrived at three core themes: Novelty, Culinary Authenticity and Performance.

\begin{tabular}{|c|c|c|c|c|c|}
\hline & & First $\mathrm{C}$ & & Second Cycle & \\
\hline Text & $\begin{array}{l}\text { Subject } \\
\text { Position }\end{array}$ & Genre & Keywords & Category & \\
\hline How To Eat... & & Title & & & \\
\hline $\begin{array}{l}\text { Toronto is a rich stew of } \\
\text { ethnic diversity, and so } \\
\text { too are the city's food } \\
\text { options. }\end{array}$ & Toronto & $\begin{array}{l}\text { Indicative } \\
\text { Statement } \\
\text { (IS) }\end{array}$ & $\begin{array}{l}\text { Rich stew } \\
\text { Ethnic diversity } \\
\text { City } \\
\text { Food option }\end{array}$ & Options & \\
\hline $\begin{array}{l}\text { Want to try something } \\
\text { new but are feeling a } \\
\text { little intimidated? }\end{array}$ & Eater & & $\begin{array}{l}\text { New } \\
\text { Feeling } \\
\text { Intimidated } \\
\end{array}$ & New & Novelty \\
\hline $\begin{array}{l}\text { Here are our fun step-by- } \\
\text { step guides that will } \\
\text { have you eating like a } \\
\text { pro. }\end{array}$ & $\begin{array}{l}\text { Way of } \\
\text { eating }\end{array}$ & & $\begin{array}{l}\text { Fun } \\
\text { Step-by-step } \\
\text { Eating like a pro }\end{array}$ & Etiquette & Authenticity \\
\hline $\begin{array}{l}\text { Find them below: } \\
\text { Ramen/ Ethiopian Injera/ } \\
\text { Burrito/ Sushi/ } \\
\text { Vietnamese Ban Hoi }\end{array}$ & Food & & & Options & Novelty \\
\hline How To Eat Ramen & & Title & & & \\
\hline $\begin{array}{l}\text { 1.Take a moment to } \\
\text { breathe in the delicious } \\
\text { umami scent. }\end{array}$ & Eater & $\begin{array}{l}\text { Body } \\
\text { Imperative } \\
\text { Statement } \\
\text { (BI) }\end{array}$ & $\begin{array}{l}\text { Moment } \\
\text { Breathe } \\
\text { Delicious } \\
\text { Umami Scent }\end{array}$ & Exotic taste & Performance \\
\hline $\begin{array}{l}\text { It's good for your } \\
\text { sinuses, but it's even } \\
\text { better for your soul. }\end{array}$ & Food & IS & $\begin{array}{l}\text { Sinus } \\
\text { Soul }\end{array}$ & $\begin{array}{l}\text { Health \& } \\
\text { Spiritual }\end{array}$ & Novelty \\
\hline $\begin{array}{l}\text { 2.Pick up the } \\
\text { chopsticks. }\end{array}$ & Eater & $\mathrm{BI}$ & Chopsticks & Etiquette & Performance \\
\hline $\begin{array}{l}\text { Ramen isn't the watery } \\
\text { broth you make out of a } \\
\text { packet when you have a } \\
\text { cold, it's a full noodle }\end{array}$ & Food & IS & $\begin{array}{l}\text { Cold } \\
\text { Full noodle } \\
\text { experience } \\
\text { Proper } \\
\end{array}$ & Exotic taste & Novelty \\
\hline
\end{tabular}




\begin{tabular}{|c|c|c|c|c|c|}
\hline $\begin{array}{l}\text { experience that requires } \\
\text { proper utensils. }\end{array}$ & & & & & \\
\hline 3. Eat noodles first. & Eater & $\mathrm{BI}$ & First & Etiquette & Performance \\
\hline $\begin{array}{l}\text { The noodles soak up the } \\
\text { flavour of the broth, so } \\
\text { be prepared for a full } \\
\text { mouth experience. }\end{array}$ & Food & IS & $\begin{array}{l}\text { Soak up } \\
\text { Flavour } \\
\text { Prepared } \\
\text { Full mouth } \\
\text { experience }\end{array}$ & Exotic taste & Novelty \\
\hline 4. Slurp away. & Eater & $\mathrm{BI}$ & Slurp & Etiquette & Performance \\
\hline $\begin{array}{l}\text { Diners are expected to } \\
\text { slurp their ramen, so } \\
\text { don't be afraid of } \\
\text { making some noise, loud } \\
\text { and proud. }\end{array}$ & Eater & $\begin{array}{l}\text { Feeling } \\
\text { Imperative } \\
\text { Statement } \\
\text { (FI) }\end{array}$ & $\begin{array}{l}\text { Expected } \\
\text { Don't be afraid } \\
\text { Noise } \\
\text { Loud } \\
\text { Proud }\end{array}$ & Etiquette & Performance \\
\hline $\begin{array}{l}\text { 5. Eat the other } \\
\text { toppings. }\end{array}$ & Eater & $\mathrm{BI}$ & Other & Etiquette & Performance \\
\hline $\begin{array}{l}\text { Once you're done with } \\
\text { the noodles, tuck into the } \\
\text { other delicious parts of } \\
\text { the ramen like menma } \\
\text { (bamboo shoots), negi } \\
\text { (shredded onions) or } \\
\text { moyashi (bean sprouts). }\end{array}$ & Eater & BI & $\begin{array}{l}\text { Other parts } \\
\text { Menma } \\
\text { Negi } \\
\text { Moyashi }\end{array}$ & $\begin{array}{l}\text { Options, } \\
\text { etiquette, } \\
\text { exotic taste }\end{array}$ & $\begin{array}{l}\text { Novelty, } \\
\text { performance }\end{array}$ \\
\hline 6. Enjoy the broth. & Eater & $\begin{array}{l}\text { FI, } \\
\text { Cognitive } \\
\text { Imperative } \\
\text { Statement } \\
\text { (CI) }\end{array}$ & Enjoy & & Performance \\
\hline $\begin{array}{l}\text { Finish your flavourful } \\
\text { journey by savouring } \\
\text { the rich broth. }\end{array}$ & Eater & $\mathrm{BI}$ & $\begin{array}{l}\text { Flavourful } \\
\text { journey } \\
\text { Savouring }\end{array}$ & Exotic taste & Novelty \\
\hline $\begin{array}{l}\text { 7. Daydream of next } \\
\text { bowl. }\end{array}$ & Eater & CI & $\begin{array}{l}\text { Daydream } \\
\text { Next }\end{array}$ & Future & Performance \\
\hline $\begin{array}{l}\text { With so many different } \\
\text { kinds of ramen, your } \\
\text { tastebuds will never get } \\
\text { bored. }\end{array}$ & Eater & IS & $\begin{array}{l}\text { Different kinds, } \\
\text { Bored }\end{array}$ & Options & Novelty \\
\hline $\begin{array}{l}\text { How To Eat Ethiopian } \\
\text { Food (Injera) }\end{array}$ & & Title & Ethiopian & & \\
\hline 1. Choose your stews. & Eater & $\mathrm{BI}$ & Choose & Options & Performance \\
\hline $\begin{array}{l}\text { Injera is like a giant } \\
\text { sourdough crepe with } \\
\text { portions of fragrant } \\
\text { stews on top. }\end{array}$ & Food & IS & $\begin{array}{l}\text { Like... } \\
\text { sourdough crepe }\end{array}$ & Exotic taste & Novelty \\
\hline $\begin{array}{l}\text { You can choose a variety } \\
\text { of different toppings, }\end{array}$ & Eater & IS & $\begin{array}{l}\text { Variety } \\
\text { Different }\end{array}$ & Options & Novelty \\
\hline
\end{tabular}




\begin{tabular}{|c|c|c|c|c|c|}
\hline $\begin{array}{l}\text { from meat- based dishes } \\
\text { to vegetarian options. }\end{array}$ & & & Options & & \\
\hline 2. Tear it up. & Eater & BI & & Etiquette & Performance \\
\hline $\begin{array}{l}\text { With your fingers, tear } \\
\text { off a piece of the spongy } \\
\text { injera. }\end{array}$ & Eater & $\mathrm{BI}$ & Fingers & Etiquette & Performance \\
\hline $\begin{array}{l}\text { 3. Grab the food (with } \\
\text { your right hand). }\end{array}$ & Eater & BI & Right hand & Etiquette & $\begin{array}{l}\text { Performance, } \\
\text { authenticity }\end{array}$ \\
\hline $\begin{array}{l}\text { Use the injera to scoop } \\
\text { up a bite of the toppings. }\end{array}$ & Eater & BI & & Etiquette & Performance \\
\hline $\begin{array}{l}\text { It's considered polite to } \\
\text { just use your right hand } \\
\text { for this. }\end{array}$ & $\begin{array}{l}\text { Way of } \\
\text { Eating }\end{array}$ & IS & Polite & Etiquette & Authenticity \\
\hline 4. Pop it in your mouth. & Eater & $\mathrm{BI}$ & & & \\
\hline $\begin{array}{l}\text { Enjoy the deliciousness } \\
\text { of the tangy injera and } \\
\text { savoury stew. }\end{array}$ & Eater & FI & Enjoy & Exotic taste & Performance \\
\hline 5. Repeat. & Eater & $\mathrm{BI}$ & & More options & Performance \\
\hline $\begin{array}{l}\text { Keep on using the injera } \\
\text { to spoon bites of stew } \\
\text { into your mouth until the } \\
\text { injera is all gone. }\end{array}$ & Eater & BI & & & Performance \\
\hline $\begin{array}{l}\text { 6. Plan your next injera } \\
\text { session. }\end{array}$ & Eater & CI & $\begin{array}{l}\text { Plan } \\
\text { Session }\end{array}$ & Future & Performance \\
\hline $\begin{array}{l}\text { The variety of stews are } \\
\text { endless, so get ready to } \\
\text { get hooked on sampling } \\
\text { different types and } \\
\text { finding your favourite. }\end{array}$ & Food & $\mathrm{CI}$ & $\begin{array}{l}\text { Variety } \\
\text { Endless } \\
\text { Hooked } \\
\text { Sampling } \\
\text { Finding } \\
\text { Favourite }\end{array}$ & $\begin{array}{l}\text { Options, exotic } \\
\text { taste }\end{array}$ & Novelty \\
\hline How To Fold A Burrito & & Title & & & \\
\hline $\begin{array}{l}\text { 1. Build your burrito } \\
\text { right. }\end{array}$ & Eater & BI & Right & Etiquette & Authenticity \\
\hline $\begin{array}{l}\text { Grab a tortilla while it's } \\
\text { warm so it's not too stiff } \\
\text { and prone to breaking, } \\
\text { and make sure not to } \\
\text { overfill it. }\end{array}$ & Eater & BI & $\begin{array}{l}\text { Stiff } \\
\text { Breaking } \\
\text { Overfill }\end{array}$ & & Performance \\
\hline $\begin{array}{l}\text { The only explosion you } \\
\text { want here is a flavour } \\
\text { explosion. }\end{array}$ & Eater & $\mathrm{CI}$ & $\begin{array}{l}\text { Explosion } \\
\text { Want } \\
\text { Flavour } \\
\text { explosion }\end{array}$ & Exotic taste & Novelty \\
\hline 2. Add your fillings. & Eater & $\mathrm{BI}$ & & Options & Performance \\
\hline $\begin{array}{l}\text { Whether you're all about } \\
\text { the veggies or need meat }\end{array}$ & Eater & IS & $\begin{array}{l}\text { Veggies } \\
\text { Meat }\end{array}$ & $\begin{array}{l}\text { Options, } \\
\text { etiquette }\end{array}$ & $\begin{array}{l}\text { Novelty, } \\
\text { authenticity }\end{array}$ \\
\hline
\end{tabular}




\begin{tabular}{|c|c|c|c|c|c|}
\hline $\begin{array}{l}\text { to keep you going, you } \\
\text { can't go wrong with a } \\
\text { mix of protein, cheese, } \\
\text { beans, rice and of } \\
\text { course, salsa, sour cream } \\
\text { and guac. }\end{array}$ & & & Can't go wrong & & \\
\hline 3. Fold it up. & Eater & BI & & Etiquette & Performance \\
\hline $\begin{array}{l}\text { Once you've decided on } \\
\text { the right bean-to-cheese } \\
\text { ratio for you, pull the } \\
\text { bottom half of the tortilla } \\
\text { over the top so it's nice, } \\
\text { compact, and ready to } \\
\text { roll. }\end{array}$ & Eater & $\mathrm{BI}$ & Right & Etiquette & Authenticity \\
\hline 4. Tuck in each side. & Eater & BI & & Etiquette & Performance \\
\hline $\begin{array}{l}\text { Fold in one side of the } \\
\text { tortilla, and then the } \\
\text { other. }\end{array}$ & Eater & $\mathrm{BI}$ & & Etiquette & Performance \\
\hline 5. Roll to perfection. & Eater & BI & Perfection & Etiquette & Performance \\
\hline $\begin{array}{l}\text { With both ends tucked } \\
\text { in, tightly roll the } \\
\text { burrito. }\end{array}$ & Eater & $\mathrm{BI}$ & & Etiquette & Performance \\
\hline 6. Enjoy. & Eater & FI, CI & Enjoy & & \\
\hline $\begin{array}{l}\text { Once your burrito is } \\
\text { rolled to perfection, take } \\
\text { a big bite and savour the } \\
\text { fresh taste and your fresh } \\
\text { skills. }\end{array}$ & Eater & $\mathrm{BI}, \mathrm{CI}$ & $\begin{array}{l}\text { Perfection } \\
\text { Savour } \\
\text { Fresh } \\
\text { Taste } \\
\text { Skills }\end{array}$ & $\begin{array}{l}\text { Etiquette, } \\
\text { exotic taste }\end{array}$ & $\begin{array}{l}\text { Authenticity, } \\
\text { novelty }\end{array}$ \\
\hline How To Eat Sushi & & Title & & & \\
\hline 1. Choose your roll. & Eater & $\mathrm{BI}$ & & Etiquette & Performance \\
\hline $\begin{array}{l}\text { There are tons of } \\
\text { different types of sushi } \\
\text { out there, so choose the } \\
\text { one that suits your tastes. }\end{array}$ & Eater & BI & $\begin{array}{l}\text { Tons } \\
\text { Different } \\
\text { Types } \\
\text { Choose } \\
\text { Suits } \\
\text { Tastes } \\
\end{array}$ & Options & Novelty \\
\hline $\begin{array}{l}\text { Whether you're into } \\
\text { simple fish rolls or the } \\
\text { creamy deep-fried } \\
\text { extravaganza, they're all } \\
\text { good choices. }\end{array}$ & Food & IS & $\begin{array}{l}\text { Simple } \\
\text { Extravaganza } \\
\text { Good choices }\end{array}$ & $\begin{array}{l}\text { Options, exotic } \\
\text { taste }\end{array}$ & $\begin{array}{l}\text { Authenticity, } \\
\text { novelty }\end{array}$ \\
\hline $\begin{array}{l}\text { 2. Prep your } \\
\text { chopsticks. }\end{array}$ & Eater & BI & & Etiquette & Performance \\
\hline $\begin{array}{l}\text { The wood that joins the } \\
\text { chopsticks at the end }\end{array}$ & Utensil & $\mathrm{BI}$ & Chopsticks & Etiquette & Performance \\
\hline
\end{tabular}




\begin{tabular}{|c|c|c|c|c|c|}
\hline $\begin{array}{l}\text { breaks off, setting your } \\
\text { chopsticks free and } \\
\text { providing a rest for them } \\
\text { for the rare moment } \\
\text { when they're not in use. }\end{array}$ & & & & & \\
\hline 3. Pour the soy sauce. & Eater & BI & & Etiquette & Performance \\
\hline $\begin{array}{l}\text { Fill up the small dish } \\
\text { only partially, and refill } \\
\text { as needed. }\end{array}$ & Eater & $\mathrm{BI}$ & & Etiquette & Performance \\
\hline $\begin{array}{l}\text { 4. Pick up your first } \\
\text { piece. }\end{array}$ & Eater & BI & & Etiquette & Performance \\
\hline $\begin{array}{l}\text { Hold the chopstick about } \\
\text { a third of the way down } \\
\text { between your index and } \\
\text { middle finger and use } \\
\text { your thumb to steady it. }\end{array}$ & Eater & $\mathrm{BI}$ & $\begin{array}{l}\text { Chopstick } \\
\text { Finger } \\
\text { Thumb }\end{array}$ & Etiquette & Performance \\
\hline $\begin{array}{l}\text { Position the second } \\
\text { chopstick in the crook } \\
\text { between your thumb and } \\
\text { index finger, and then } \\
\text { use the first chopstick to } \\
\text { pinch a piece of sushi. }\end{array}$ & Eater & BI & $\begin{array}{l}\text { Chopstick } \\
\text { Thumb } \\
\text { Finger }\end{array}$ & Etiquette & Performance \\
\hline 5. Take it in one bite. & Eater & $\mathrm{BI}$ & & Etiquette & Performance \\
\hline $\begin{array}{l}\text { It's considered rude to } \\
\text { take multiple bites of } \\
\text { one piece of sushi, not to } \\
\text { mention a huge mess. }\end{array}$ & $\begin{array}{l}\text { Way of } \\
\text { Eating }\end{array}$ & IS & Rude & Etiquette & $\begin{array}{l}\text { Authenticity, } \\
\text { performance }\end{array}$ \\
\hline $\begin{array}{l}\text { 6. Cleanse your palate } \\
\text { and repeat. }\end{array}$ & Eater & BI & $\begin{array}{l}\text { Cleanse } \\
\text { Palate }\end{array}$ & Etiquette & Performance \\
\hline $\begin{array}{l}\text { Use the ginger served } \\
\text { alongside sushi to reset } \\
\text { your mouth between } \\
\text { rolls. }\end{array}$ & Eater & $\mathrm{BI}$ & & Etiquette & Performance \\
\hline $\begin{array}{l}\text { Not only is it a digestive } \\
\text { aid, but it helps prepare } \\
\text { your mouth for a totally } \\
\text { different, totally } \\
\text { delicious new flavour. }\end{array}$ & Food & IS & $\begin{array}{l}\text { Digestive } \\
\text { Totally different } \\
\text { Totally delicious }\end{array}$ & $\begin{array}{l}\text { Health \& } \\
\text { spiritual, } \\
\text { exotic taste }\end{array}$ & Novelty \\
\hline $\begin{array}{l}\text { How To Eat } \\
\text { Vietnamese Bahn Hoi }\end{array}$ & & Title & & & \\
\hline $\begin{array}{l}\text { 1. Get ready for some } \\
\text { serious deliciousness. }\end{array}$ & Eater & BI, CI & $\begin{array}{l}\text { Ready } \\
\text { Serious } \\
\text { deliciousness }\end{array}$ & Exotic taste & Novelty \\
\hline $\begin{array}{l}\text { Banh Hoi are tasty rice } \\
\text { noodles that are } \\
\text { compressed into a square }\end{array}$ & Food & IS & $\begin{array}{l}\text { Tasty } \\
\text { Like a... }\end{array}$ & Exotic taste & Novelty \\
\hline
\end{tabular}




\begin{tabular}{|c|c|c|c|c|c|}
\hline $\begin{array}{l}\text { sheet, like a piece of } \\
\text { cheesecloth. }\end{array}$ & & & & & \\
\hline $\begin{array}{l}\text { They're difficult to make } \\
\text { and are usually saved for } \\
\text { big celebrations }\end{array}$ & Food & IS & $\begin{array}{l}\text { Saved } \\
\text { Big celebrations }\end{array}$ & Tradition & Novelty \\
\hline 2. Pick up the lettuce. & Eater & BI & & Etiquette & Performance \\
\hline $\begin{array}{l}\text { Start by grabbing a piece } \\
\text { of lettuce that is about } \\
\text { the size of your hand. }\end{array}$ & Eater & $\mathrm{BI}$ & Start & Etiquette & Performance \\
\hline $\begin{array}{l}\text { It adds crispness and } \\
\text { keeps your hand clean } \\
\text { (ish). }\end{array}$ & Food & IS & & Etiquette & Authenticity \\
\hline 3. Add some herbs. & Eater & BI & & Etiquette & Performance \\
\hline $\begin{array}{l}\text { Layer fresh herbs that } \\
\text { are served alongside the } \\
\text { Banh Hoi. }\end{array}$ & Eater & $\mathrm{BI}$ & & Etiquette & Performance \\
\hline 4. Noodles next. & Eater & $\mathrm{BI}$ & Next & Etiquette & Performance \\
\hline $\begin{array}{l}\text { Next, add a piece of } \\
\text { Banh Hoi to your } \\
\text { growing lettuce wrap. }\end{array}$ & Eater & $\mathrm{BI}$ & Next & Etiquette & Performance \\
\hline 5. Meat time. & Eater & BI & Time & Etiquette & Performance \\
\hline $\begin{array}{l}\text { Finally, include a piece } \\
\text { of meat. Bahn Hoi is } \\
\text { traditionally served with } \\
\text { tasty grilled meats like } \\
\text { duck and beef but can } \\
\text { also be include lighter } \\
\text { proteins like shrimp and } \\
\text { chicken. }\end{array}$ & Eater & $\mathrm{BI}$ & $\begin{array}{l}\text { Finally } \\
\text { Traditionally } \\
\text { Tasty }\end{array}$ & $\begin{array}{l}\text { Exotic taste, } \\
\text { options }\end{array}$ & $\begin{array}{l}\text { Performance, } \\
\text { novelty, } \\
\text { authenticity }\end{array}$ \\
\hline 6. Wrap it together. & Eater & BI & & Etiquette & Performance \\
\hline $\begin{array}{l}\text { Fold the lettuce over so } \\
\text { it's a compact little wrap } \\
\text { that can fit in your } \\
\text { mouth. }\end{array}$ & Eater & $\mathrm{BI}$ & & Etiquette & Performance \\
\hline 7. Enjoy. & Eater & BI, FI & Enjoy & & \\
\hline $\begin{array}{l}\text { Savour the complex } \\
\text { flavours and start } \\
\text { building your next bite. }\end{array}$ & Eater & $\mathrm{CI}$ & $\begin{array}{l}\text { Savour } \\
\text { Complex } \\
\text { Start } \\
\text { Next }\end{array}$ & $\begin{array}{l}\text { Exotic taste, } \\
\text { future }\end{array}$ & $\begin{array}{l}\text { Novelty, } \\
\text { Performance }\end{array}$ \\
\hline
\end{tabular}




\section{Appendix B}

The following are screenshots of the HTE guides as found on Tourism Toronto's website. This includes a screenshot of the description that precedes the guides. Retrieved from: https://www.seetorontonow.com/cuisine/how-to-eat/\#sm.0015ibb7116g7e47z5h2ht3guppm9

Home $=\underline{\text { Cuisine }}=$ How To Eat.

> How To Eat...

Toronto is a rich stew of ethnic diversity, and so too are the city's food options. Want to try something new but are feeling a little intimidated? Here are our fun step-by-step guides that will have you eating like a pro.

Find them below: Ramen I Ethiopian Injera | Burrito | Sushi I Vietnamese Ban Hoi

\section{HOW TO EAT RAMEN} 1. Take a moment to breathe in the delicious umami scent. It's nond for vaur sinuses hut

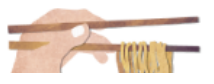

S 9 回 


\section{HOW TO EAT RAMEN}

\section{1.}

Take a moment to breathe in the delicious umami scent.

It's good for your sinuses, but it's even better for your soul.

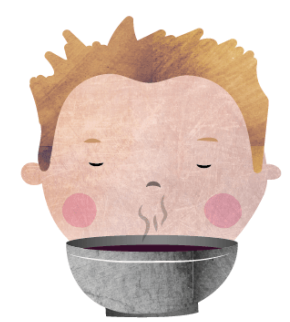

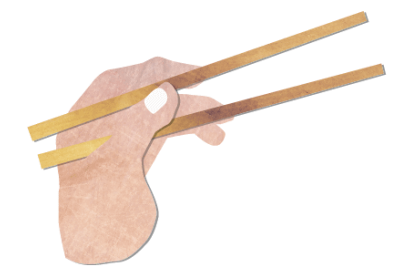

2.

Pick up the chopsticks. Ramen isn't the watery broth you make out of a packet when you have a cold, it's a full noodle experience that requires proper utensils.

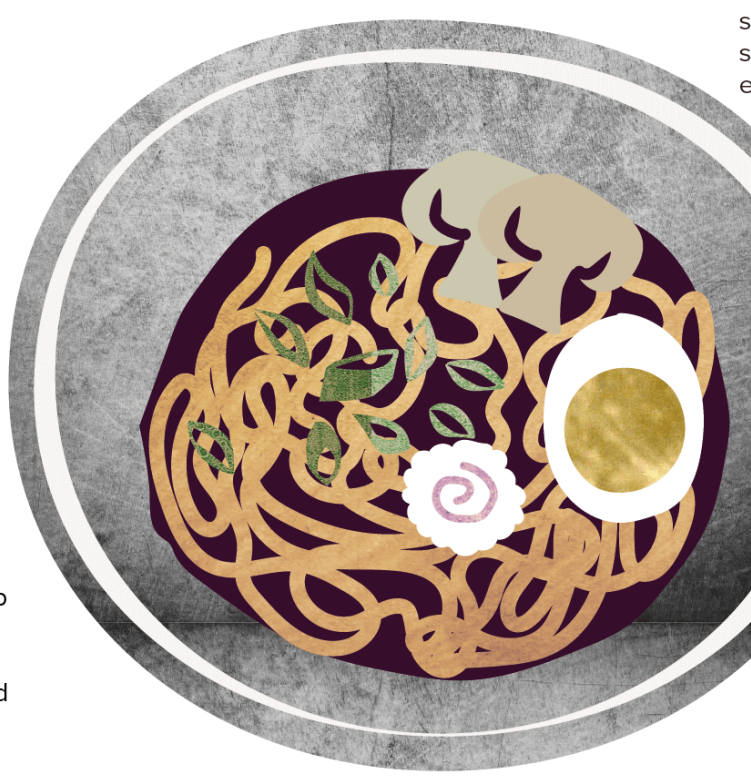

5.

Eat the other toppings. Once you're done with the noodles, tuck into the other delicious parts of the ramen like menma (bamboo shoots), negi (shredded onions) or moyashi (bean sprouts).

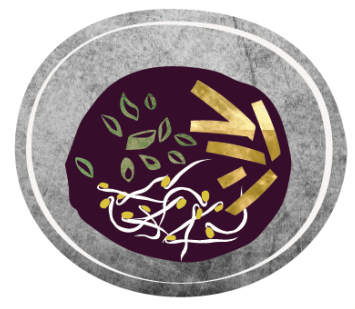

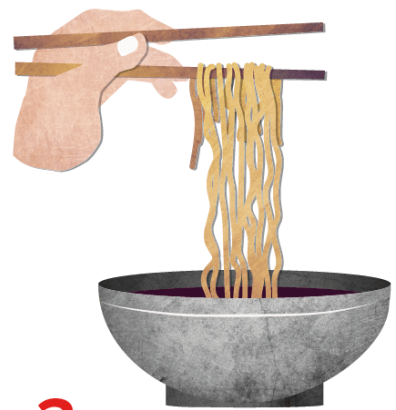

3.

Eat noodles first. The noodles soak up the flavour of the broth, so be prepared for a full mouth experience.

their ramen, so don't be afraid of making proud.
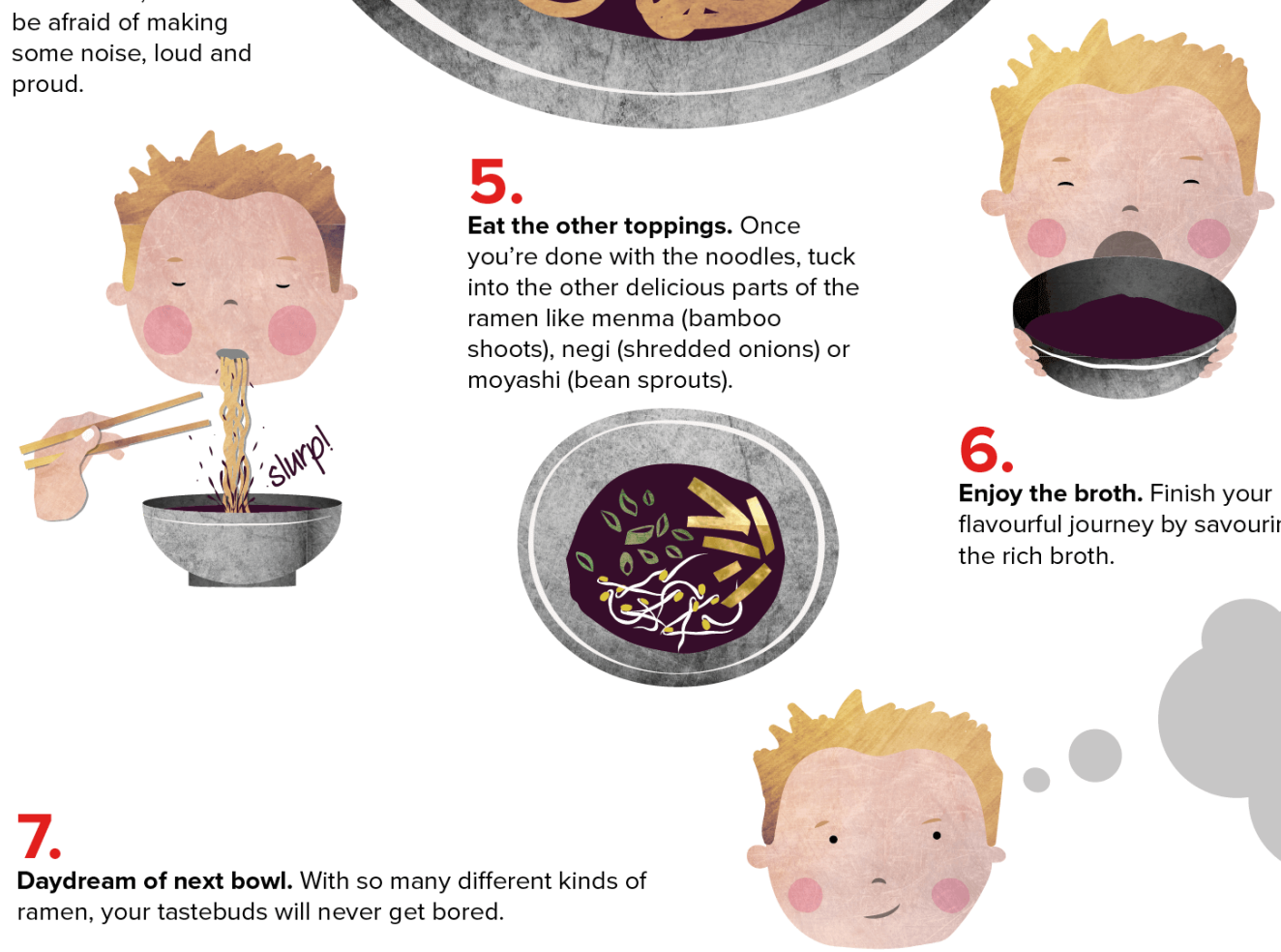

6.

Enjoy the broth. Finish your flavourful journey by savouring the rich broth.

Daydream of next bowl. With so many different kinds of ramen, your tastebuds will never get bored. 


\section{HOW TO EAT ETHIOPIAN FOOD}

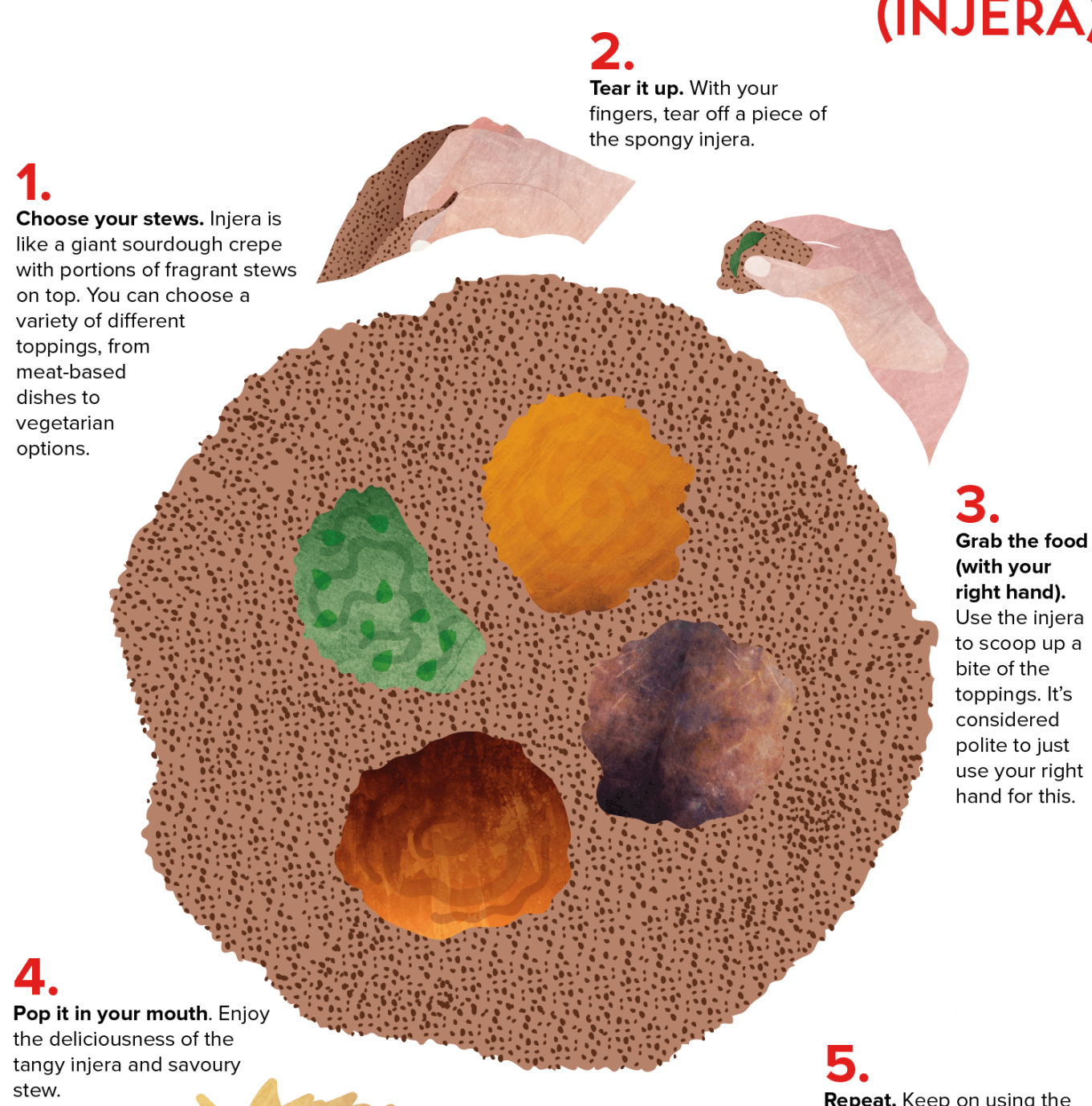

stew.

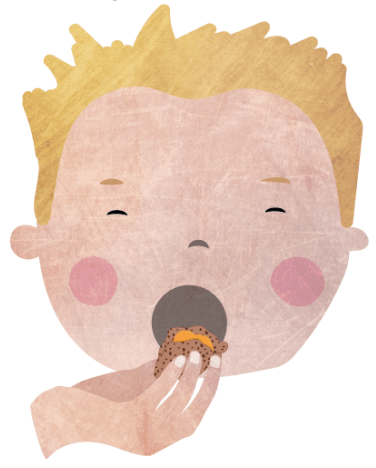

Repeat. Keep on using the injera to spoon bites of stew into your mouth until the injera is all gone.

\section{6.}

Plan your next injera session. The variety of stews are endless, so get ready to get hooked on sampling different types and finding your favourite.

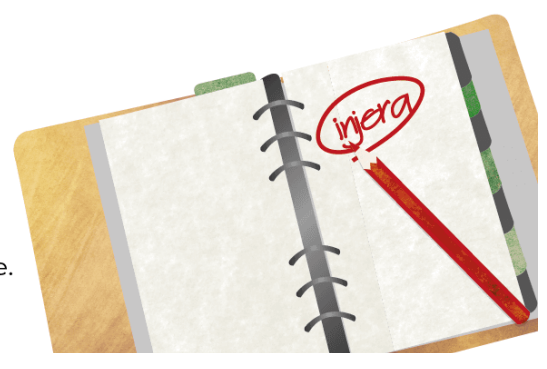




\section{HOW TO FOLD A BURRITO}

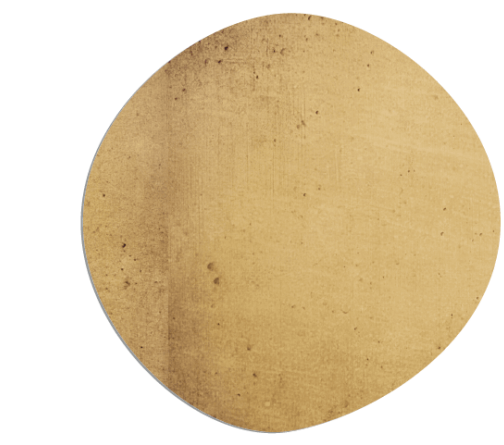

2.

Add your fillings. Whether you're all about the veggies or need meat to keep you going, you can't go wrong with a mix of protein, cheese, beans, rice, and of course, salsa, sour cream, and guac.

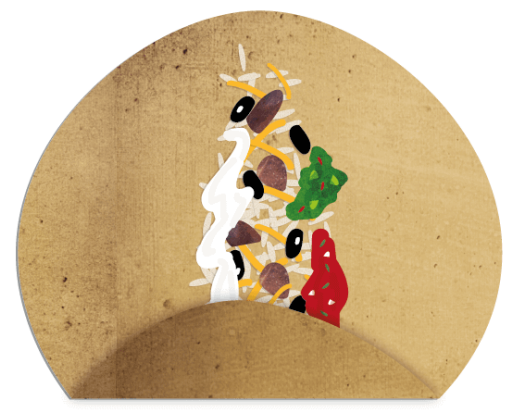

\section{3.}

Fold it up. Once you've decided on the right bean-to-cheese ratio for you, pull the bottom half of the tortilla over the top so it's nice, compact, and ready to roll.

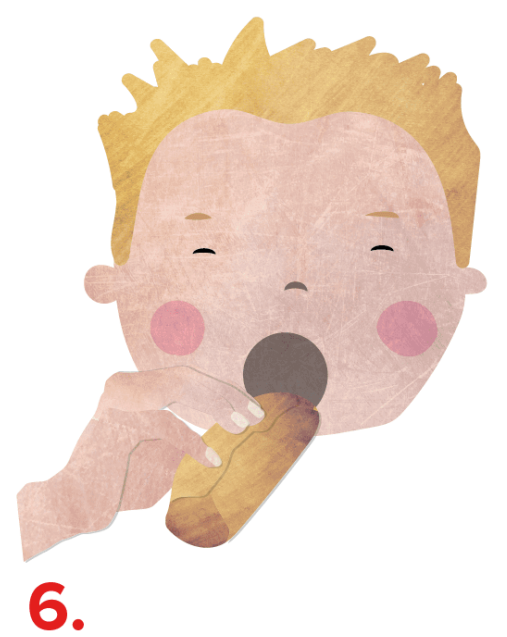

Enjoy. Once your burrito is rolled to perfection, take a big bite and savour the fresh taste and your fresh skills.

\section{1.}

Build your burrito right. Grab a tortilla while it's warm so it's not too stiff and prone to breaking, and make sure not to overfill it. The only explosion you want here is a flavour explosion.

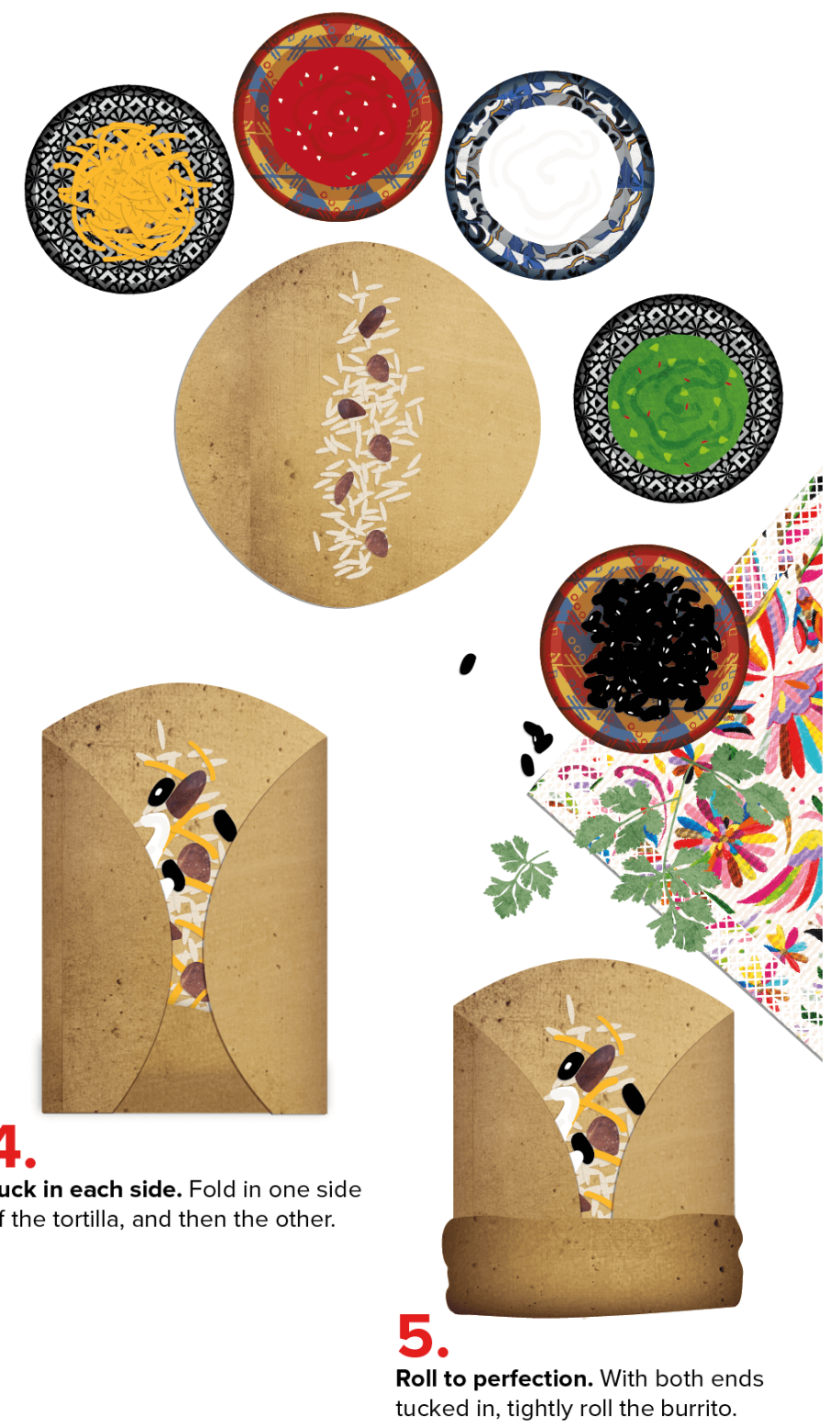

tucked in, tightly roll the burrito.

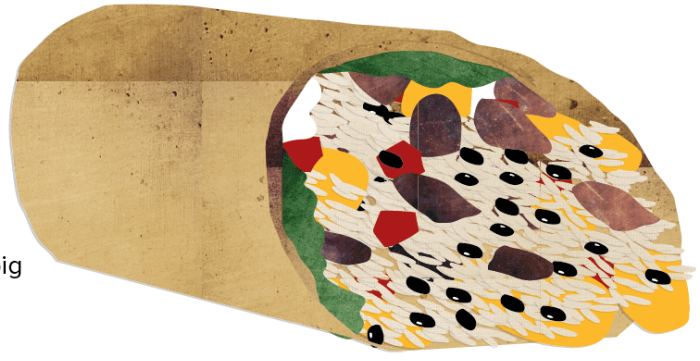




\section{HOW TO EAT SUSHI}

1. 0 - 0 .

Choose your roll. There are tons of different types of sushi out there, so choose the one that suits your tastes. Whether you're into simple fish rolls or the creamy deep-fried extravaganza, they're all good choices.

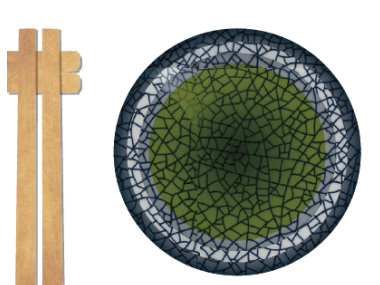

\section{2.}

Prep your chopsticks. The wood that joins the chopsticks at the end breaks off, setting your chopsticks free and providing a rest for them for the rare moment when they're not in use.

\section{3.}

Pour the soy sauce. Fill up the small dish only partially, and refill as needed.
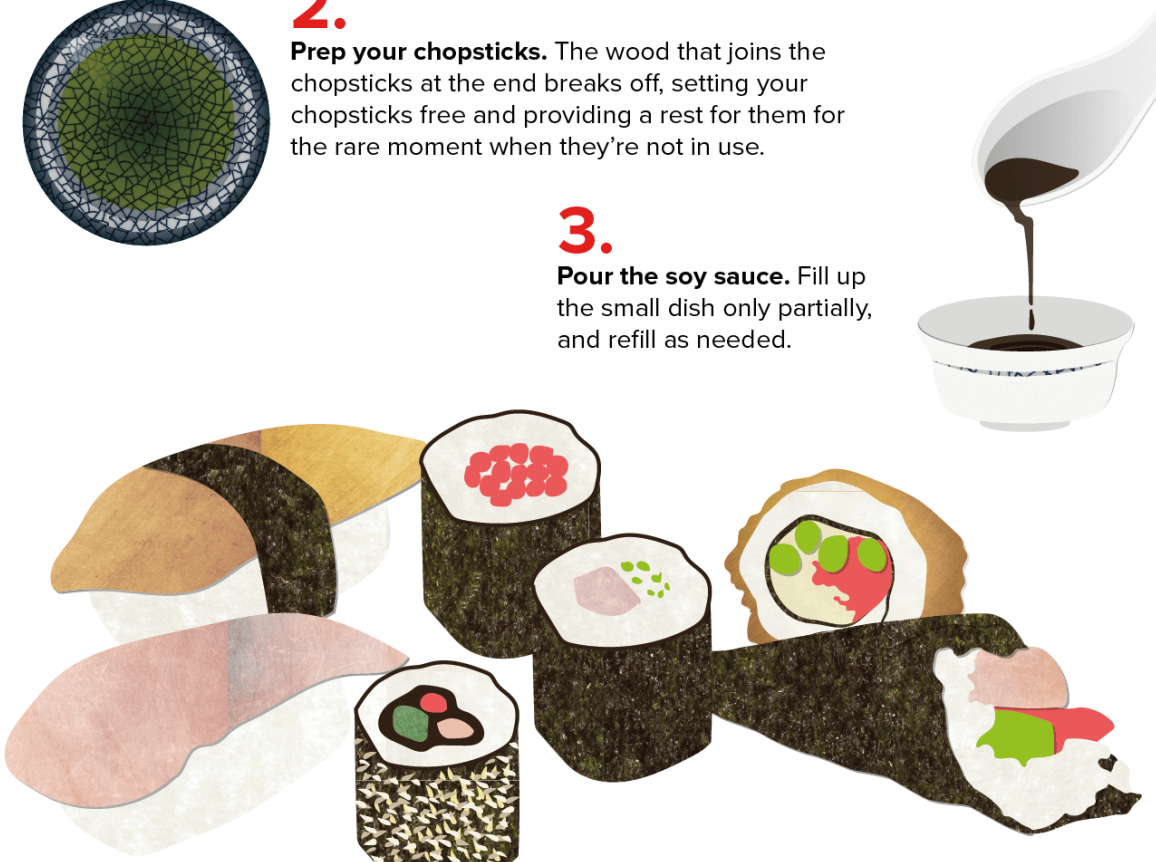

\section{4.}

Pick up your first piece. Hold the chopstick about a third of the way down between your index and middle finger, and use your thumb to steady it. Position the second chopstick in the crook between your thumb and index finger, and then use the first chopstick to pinch a piece of sushi.

\section{5.}

Take it in one bite. It's considered rude to take multiple bites of one piece of sushi, not to mention a huge mess.

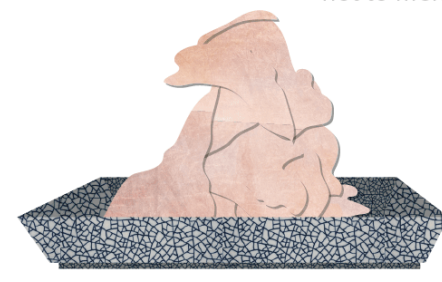

\section{6.}

Cleanse your palate and repeat. Use the ginger served alongside sushi to reset your mouth between rolls. Not only is it a digestive aid, but it helps prepare your mouth for a totally different, totally delicious new flavour. 


\section{HOW TO EAT VIETNAMESE BANH HOI}

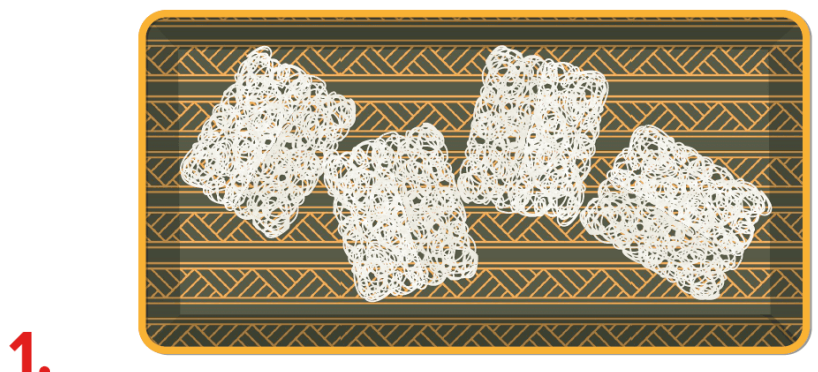

Get ready for some serious deliciousness. Banh Hoi are tasty rice noodles that are compressed into a square sheet, like a piece of cheesecloth. They're difficult to make and are usually saved for big celebrations.

\section{2.}

Pick up the lettuce. Start by grabbing a piece of lettuce that is about the size of your hand. It adds crispness and keeps your hand clean (ish).
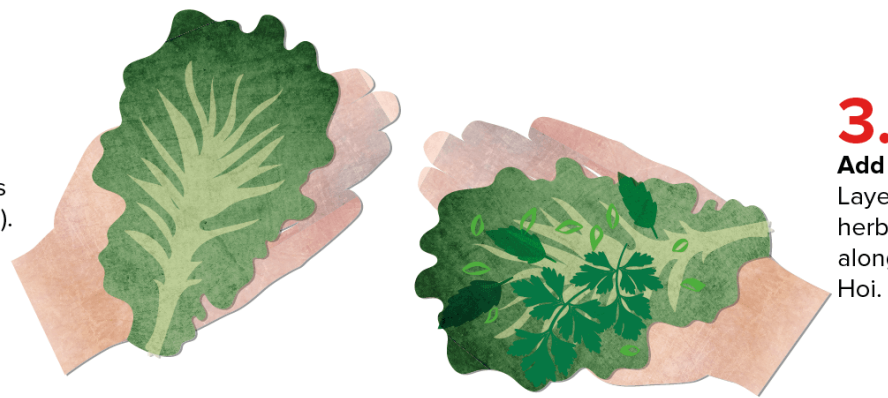

Add some herbs.

Layer a few fresh

herbs that are served

alongside the Banh Hoi.

5.

Meat time. Finally, include

a piece of meat. Banh Hoi is

traditionally served with tasty

grilled meats like duck and beef, but

can also be include lighter proteins

like shrimp and chicken.

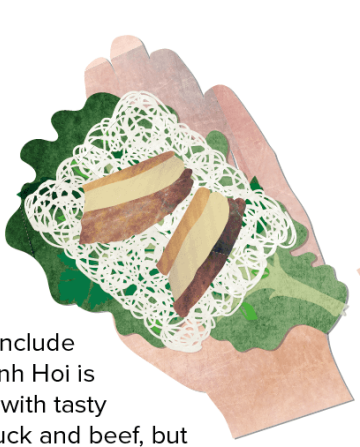

4.

Noodles next.

Next, add a piece of

Banh Hoi to your

growing lettuce wrap.
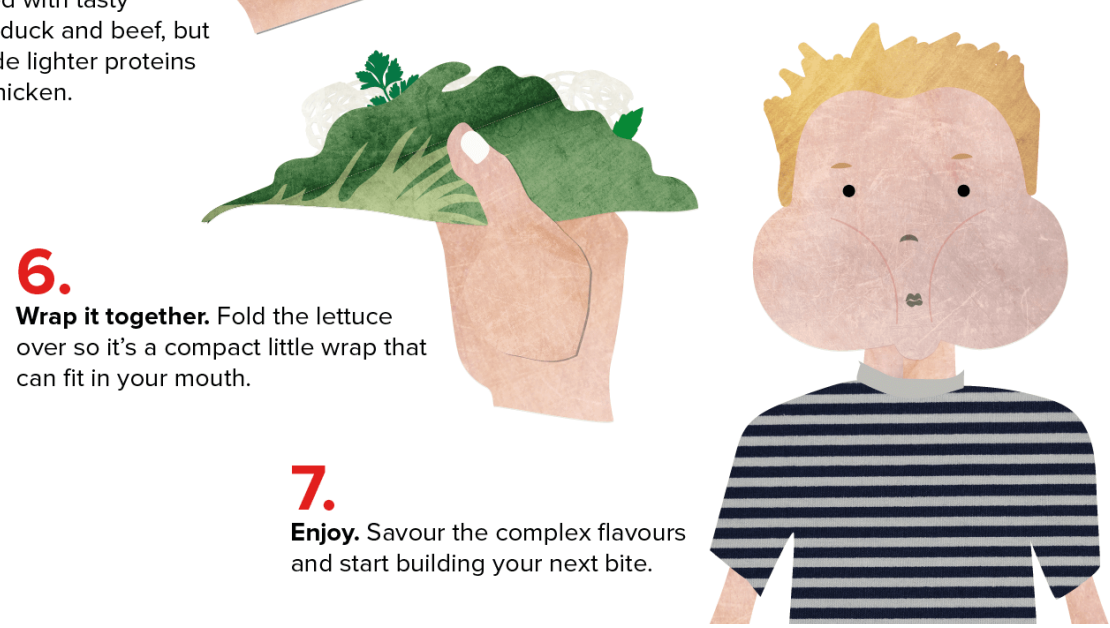


\section{References}

Alibhai-Brown, Y. (2000). After multiculturalism. Foreign Policy Centre.

Ashcroft, B., Griffiths, G., \& Tiffin, H. (2006). The post-colonial studies reader. New York: Routledge.

Bhabha, H. K. (1994). Introduction: Locations of culture. The Location of Culture, 1-18.

Bell, D., \& Valentine, G. (1995). Consuming geographies: We are where we eat. London: Routledge.

Blunt, A., \& McEwan, C. (2002). Postcolonial geographies Continuum. New York.

Blunt, A., \& Wills, J. (2016). Dissident geographies: An introduction to radical ideas and practice. Routledge.

Butler, J. (1990) Gender Trouble: Feminism and the Subversion of Identity. New York: Routledge.

Butler, J. (1993) Bodies That Matter: On the Discursive Limits of "Sex". New York: Routledge.

Cappeliez, S., \& Johnston, J. (2013). From meat and potatoes to "real-deal" rotis: Exploring everyday culinary cosmopolitanism. Poetics, 41(5), 433-455.

City of Toronto. (2018). Toronto at a Glance. Retrieved from https://www.toronto.ca/citygovernment/data-research-maps/toronto-at-a-glance/

City of Toronto. (2018b). Strong Economy. Retrieved from https://www.toronto.ca/businesseconomy/invest-in-toronto/strong-economy/

City of Toronto. (2018c). Global City. Retrieved from https://www.toronto.ca/businesseconomy/invest-in-toronto/global-city/

Clammer, J. (2015). Performing ethnicity: Performance, gender, body and belief in the construction and signalling of identity. Ethnic and Racial Studies, 38(13), 2159-2166.

https://doi.org/10.1080/01419870.2015.1045305 
Cook, I. (2008). Geographies of food: Mixing. Progress in Human Geography, 32(6), 821-833. https://doi.org/10.1177/0309132508090979

Cook, I., \& Harrison, M. (2003). Cross over food: Re-materializing postcolonial geographies. Transactions of the Institute of British Geographers, 28(3), 296-317.

Creswell, J. W. (2003). Research design: Qualitative, quantitative, and mixed method approaches (2nd ed). Thousand Oaks, Calif: Sage Publications.

Daily Bread Food Bank. (2018). Who's Hungry: 2018 A Profile of Hunger in Toronto. Retrieved from https:/www.dailybread.ca/wp-content/uploads/2018/10/Whos-Hungry-2018-full-3.pdf

Devadason, R. (2010). Cosmopolitanism, Geographical Imaginaries and Belonging in North London.

Urban Studies, 47(14), 2945-2963. https://doi.org/10.1177/0042098009360228

Dirlik, A. (1994). The postcolonial aura: Third World criticism in the age of global capitalism. Critical Inquiry, 20(2), 328-356.

Duruz, J. (2004). Adventuring and Belonging: An Appetite for Markets. Space and Culture, 7(4), 427-445. https://doi.org/10.1177/1206331204269380

Duruz, J. (2005). Eating at the Borders: Culinary Journeys. Environment and Planning D: Society and Space, 23(1), 51-69. https://doi.org/10.1068/d52j

Duruz, J. (2010). Floating food: Eating 'Asia' in kitchens of the diaspora. Emotion, Space and Society, 3(1), 45-49. https://doi.org/10.1016/j.emospa.2009.08.002

Duruz, J. (2011). Tastes of hybrid belonging: Following the laksa trail in Katong, Singapore. Continuum, 25(5), 605-618. https://doi.org/10.1080/10304312.2011.597843

Duruz, J., Luckman, S., \& Bishop, P. (2011). Bazaar encounters: Food, markets, belonging and citizenship in the cosmopolitan city. Continuum, 25(5), 599-604.

https://doi.org/10.1080/10304312.2011.605520 
Fanon, F. (1967). Black Skin, White Masks. New York: Grove Press.

Florida, R. (2003). Cities and the Creative Class. City and Community, 2(1), 3-19. https://doi.org/10.1111/1540-6040.00034

Flowers, R., \& Swan, E. (2012). Eating the Asian Other? Pedagogies of Food Multiculturalism in Australia. PORTAL Journal of Multidisciplinary International Studies, 9(2). https://doi.org/10.5130/portal.v9i2.2370

Gandhi, L. (2019). Postcolonial theory: A critical introduction. New York: Columbia University Press.

Gates, H. L. (1993). Loose canons: Notes on the culture wars. Oxford University Press on Demand. Grey, S., \& Newman, L. (2018). Beyond culinary colonialism: Indigenous food sovereignty, liberal multiculturalism, and the control of gastronomic capital. Agriculture and Human Values, 35(3), 717-730. https://doi.org/10.1007/s10460-018-9868-2

Gunew, S. (1993). Against multiculturalism: Rhetorical images. Multiculturalism, Difference and Postmodernism, 33, 53.

Gunew, S. M. (1994). Framing marginality: Multicultural literary studies. Carlton, Vic.: Melbourne University Press.

Gunew, S. (2000). Introduction: Multicultural translations of food, bodies, language. Journal of Intercultural Studies, 21(3), 227-237. https://doi.org/10.1080/713678979

Hackworth, J. R., \& Rekers, J. (2005). Ethnic identity, place marketing, and gentrification in Toronto. Centre for Urban and Community Studies, University of Toronto.

Hage, G. (1997). At home in the entrails of the west: Multiculturalism, ethnic food and migrant homebuilding. Home/World: Space, Community and Marginality in Sydney's West, 99-153. 
Hall, C. (1993). White Visions, Black Lives: The Free Villages of Jamaica. History Workshop Journal, 36(1), 100-132. https://doi.org/10.1093/hwj/36.1.100

Hall, S. (1992). The West and the rest: Discourse and power. Cambridge.

Hamlin, D., \& Davies, S. (2016). Toronto: A new global city of learning. London Review of Education, 14(2), 186-198. https://doi.org/10.18546/LRE.14.2.13

Heldke, L. M. (2003). Exotic appetites: Ruminations of a food adventurer. New York: Routledge. hooks, B. (1992). Eating the Other: Desire and Resistance. Black Looks: Race and Representation. Boston: South End Press, 21-39.

Hulchanski, J. D. (2011). The three cities within Toronto. Toronto: Cities Centre.

Jackson, P., \& Jacobs, J. M. (1996). Postcolonialism and the politics of race. Environment and Planning D Abstract, 14(1), 1-3.

Jacobs, J. M (1996). Edge of Empire: Postcolonialism and the city. London: Routledge.

Jacobs, J. M. (1998). Staging difference: Aestheticization and the politics of difference in contemporary cities. Cities of Difference, 252-278.

Jacobs, J. M. \& Fincher, R., (1998) Introduction. In R Fincher and J M Jacobs (eds), Cities of Difference. New York: Guildford, 1-16

Katz, C. (2001). On the Grounds of Globalization: A Topography for Feminist Political Engagement. Signs: Journal of Women in Culture and Society, 26(4), 1213-1234. https://doi.org/10.1086/495653

Kipfer, S., \& Keil, R. (2002). Toronto Inc? Planning the Competitive City in the New Toronto. Antipode, 34(2), 227-264. https://doi.org/10.1111/1467-8330.00237

Koç, M., \& Welsh, J. (2001). Food, foodways and immigrant experience. Toronto: Centre for Studies in Food Security, 2, 46-48. 
Koç, M., Soo, K., \& Willa Liu, L. (n.d.). Newcomer Food Security and Safety. In Immigrant Experiences in North America: Understanding Settlement and Integration (pp. 292-311). Toronto: Canadian Scholars' Press.

Kymlicka, W. (2004). Marketing Canadian pluralism in the international arena. International Journal, 59(4), 829-852.

Kymlicka, W. (2010). The rise and fall of multiculturalism? New debates on inclusion and accommodation in diverse societies. International Social Science Journal, 61(199), 97-112.

Lessa, I., \& Rocha, C. (2012). Regrounding in infertile soil. Canadian Social Work Review, $29(2), 18$. Loomba, A. (2007). Colonialism/Postcolonialism. New York: Routledge.

Maynard, M., Dean, J., Rodriguez, P. I., Sriranganathan, G., Qutub, M., \& Kirkpatrick, S. I. (2019). The Experience of Food Insecurity Among Immigrants: A Scoping Review. Journal of International Migration and Integration, 20(2), 375-417. https://doi.org/10.1007/s12134-018$\underline{0613-\mathrm{X}}$

McClinchey, K. A. (2008). Urban ethnic festivals, neighborhoods, and the multiple realities of marketing place. Journal of Travel \& Tourism Marketing, 25(3-4), 251-264.

Moffat, T., Mohammed, C., \& Newbold, K. B. (2017). Cultural Dimensions of Food Insecurity among Immigrants and Refugees. Human Organization, 76(1), 15-27. https://doi.org/10.17730/0018-7259.76.1.15

Narayan, U. (1997). Dislocating cultures: Identities, traditions, and third world feminism. New York: Routledge.

Nash, C. (2002). Cultural geography: Postcolonial cultural geographies. Progress in Human Geography, 26(2), 219-230. https://doi.org/10.1191/0309132502ph365pr

Nugent, D., \& Vincent, J. (2008). A Companion to the Anthropology of Politics. John Wiley \& Sons. 
Ray, K. (2016). The ethnic restaurateur. Bloomsbury Publishing.

Razack, S. (2002). When place becomes race: Introduction. Race, Space and the Law: Unmapping a White Settler Society, 1-21.

Saggar, S. A. (2018). “Memories from my mother's kitchen”: Extinction and anxiety in Joudie Kalla's Palestine on a Plate. Journal of Postcolonial Writing, 54(4), 456-468.

Said, E. (1978). Orientalism. New York: Pantheon, 80.

Saldaña, J. (2015). The coding manual for qualitative researchers. Sage.

Salih, S. (2007). On Judith Butler and Performativity. Sexualities and Communication in Everyday Life: A Reader, 55-68.

Sassen, Saskia. 1991. The Global City. New York: Princeton University Press.

Schechner, R. (2013). Performance Studies. Routledge.

Schwegler Castañer, A. (2018). "A taste of elsewhere": Consuming the exotic in Simone Lazaroo's Sustenance. Journal of Postcolonial Writing, 15.

Shankar, S., \& Cavanaugh, J. R. (2012). Language and materiality in global capitalism. Annual Review of Anthropology, 41, 355-369.

Slocum, R. (2011). Race in the study of food. Progress in Human Geography, 35(3), 303-327. https://doi.org/10.1177/0309132510378335

Spivak, G. C. (1988). Can the subaltern speak? Marxism and the interpretation of culture. Urbana: University of Illinois Press, 271-313.

Tarasuk, V, Mitchell, A, Dachner, N. (2016). Household food insecurity in Canada, 2014.Toronto: Research to identify policy options to reduce food insecurity (PROOF). Retrieved from https://proof.utoronto.ca/ 
Teelucksingh, C. (2009). Instant Gentrification: Social Inequality and Brownsfield Redevelopment in Downtown Toronto. UBC Press: Vancouver, Canada.

Tourism Toronto. (2019). How to Eat.... Retrieved from https://www.seetorontonow.com/cuisine/how-to-eat/

Tourism Toronto. (2019b). About Tourism Toronto. Retrieved from https://www.seetorontonow.com/about-tourism-toronto/

Van Dijk, T. A. (2001). 18 Critical discourse analysis. The Handbook of Discourse Analysis, 349371.

Welsh, S. (2018). Culinary Cultures: Food and the Postcolonial. Taylor \& Francis.

Wise, A. (2011). Moving food: Gustatory commensality and disjuncture in everyday multiculturalism. New Formations, 74(74), 82-107. 